\title{
Soil Erosion on Abandoned Land in Andalusia: A Comparison of Interrill- and Rill Erosion Rates
}

\author{
S. Wirtz, ${ }^{1}$ T. Iserloh, ${ }^{1}$ G. Rock, ${ }^{2}$ R. Hansen, ${ }^{1}$ M. Marzen, ${ }^{1}$ M. Seeger, ${ }^{1}$ S. Betz, ${ }^{1}$ \\ A. Remke, ${ }^{1}$ R. Wengel, ${ }^{1}$ V. Butzen, ${ }^{1}$ and J. B. Ries ${ }^{1}$ \\ ${ }^{1}$ Department of Physical Geography, Trier University, Behringstraße, 54286 Trier, Germany \\ ${ }^{2}$ Department of Remote Sensing, Trier University, Behringstraße, 54286 Trier, Germany
}

Correspondence should be addressed to S. Wirtz,wirtz@uni-trier.de

Received 13 July 2012; Accepted 30 August 2012

Academic Editors: J. Albergel, L. D. Chen, and Z. L. He

Copyright (c) 2012 S. Wirtz et al. This is an open access article distributed under the Creative Commons Attribution License, which permits unrestricted use, distribution, and reproduction in any medium, provided the original work is properly cited.

\begin{abstract}
The present paper is based on several field investigations (monitoring soil and rill erosion by aerial photography, rainfall simulations with portable rainfall simulators, and manmade rill flooding) in southern Spain. Experiments lead now to a closer understanding of the dynamics and power of different soil erosion processes in a gully catchment area. The test site Freila (Andalusia, Spain) covers an area of 10.01 ha with a rill density of $169 \mathrm{~m} \mathrm{ha}^{-1}$, corresponding to a total rill length of $1694 \mathrm{~m}$. Assuming an average rill width of $0.15 \mathrm{~m}$, the total rill surface can be calculated at $250 \mathrm{~m}^{2}(0.025 \mathrm{ha})$. Given that, the surface covered by rills makes up only $0.25 \%$ of the total test site. Since the rill network drains 1.98 ha, $20 \%$ of the total runoff comes from rills. The rills' sediment erosion was measured and the total soil loss was then calculated for detachment rates between $1685 \mathrm{~g} \mathrm{~m}^{-2}$ and $3018 \mathrm{~g} \mathrm{~m}^{-2}$. The interrill areas (99.75\% of the test site) show values between 29 and $143 \mathrm{~g} \mathrm{~m}^{-2}$. This suggests an important role of rill erosion concerning runoff and soil detachment.
\end{abstract}

\section{Introduction}

Soil erosion by water involves different physical processes at variable spatial and temporal scales. The two main processes are interrill- and rill erosion by runoff water; the mechanisms of these two processes are completely different. The soil detachment in interrill erosion is induced and enhanced by splash and shallow overland flow [1]. In addition, it is influenced by the intrinsic characteristics of the soils $[2-4]$ and rainfall intensity $[5,6]$. In contrast, rill erosion is caused by a concentrated overland flow [6-8]. This is considered to be the most important process of sediment erosion and soil loss $[9,10]$. As a result, the new rills can become persistent and form gullies, potentially constraining further land use [11-14]. Especially on fallow and shrub land, rills can develop without being disturbed by land management measures like ploughing. Since huge areas in the Mediterranean are covered by fallow and shrub land [15], rill erosion can be assumed to be a major process of soil erosion in the Mediterranean.
The outstanding importance of linear erosion for all intents and purposes (geomorphology, hydrology and economy) can be explained by the amount of kinetic energy of water, running as a concentrated runoff in channels. When concentrated, water reaches its maximum impact concerning erosion and transport [16]. The percentage of interrill, rill, and gully erosion on the total soil loss in a catchment area is difficult to determine, and results of many research groups differ considerably in comparing the effectiveness of the different soil erosion processes.

Results concerning the proportion of gully erosion on total soil erosion vary between $10 \%$ and more than 90\% [17]. Gullies need high-intensity rainfall events to be activated. Most thunderstorms do not activate the gully in a catchment, but are able to generate or reactivate smaller forms, the rills. Faust and Schmidt [18] considered the geomorphologic importance of gullies as quite low, corresponding to the rare activity of the gullies. They state an activity frequency of one single event in 20 years, compared with an assumed activity of the rills of about four times per year. On that 
account, the rills deliver smaller sediment quantities, but this can occur several times within one year. Meyer et al. [19] suggested a triplication of erosion rates due to rill development. Cornfields in Bedfordshire (UK) lost as much as 9 to 21 times more sediment by rill erosion, compared with erosion only affected by interrill erosion [20]. Cerdan et al. [9] reported the soil loss by rill erosion in Normandy during only a few heavy rainfall events to be up to $90 \%$ of the total soil loss.

During the last decades, several approaches have been developed to describe and predict soil detachment and sediment transport in rills in a reliable way [7, 21, 22]. In contrast, the factors influencing the development and the behaviour of rills have not been comprehensively assessed yet. The relationships between factors influencing these processes remain unclear as well. Knapen et al. [8] attribute this to the lack of comparable data that could be used for a meta-analysis on rill erosion. Furthermore, there is still little known about the function of rills in specific environments.

In this paper, the results of a set of experimental methods are used to draw conclusions from the differences between interrill- and rill erosion dynamics on a gully catchment in Andalusia (Spain). Three main questions were to be answered.

(1) Which proportion of the test site area is drained by rill networks?

(2) Which runoff intensities appear in the rills, which on the interrill areas?

(3) How effective is the rill erosion compared to the interrill erosion in the catchment?

\section{Material and Methods}

2.1. Study Area. The study area Freila is situated in the Hoya de Baza sedimentary basin (see Figure 1) in Andalusia (southeast Spain). The bedrock mostly consists of Pliocene sedimentary rocks, that is, marls and fine grained sandstones. At the surface the marls and sandstones are weathered to calcareous loamy to sandy lithosols. The semiarid climate is characterised by a mean annual temperature of about $14.2^{\circ} \mathrm{C}$. The annual precipitation is down to only $368 \mathrm{~mm}$, with a high interannual variability. The vegetation is dominated by low shrub land of Thymus vulgaris and Stipa tenacissima grassland. The land use on the southern lakeside of the Negratin reservoir is dominated by abandoned cereal fields, which are extensively grazed by flocks of sheep. Agricultural land use comprises mainly cereal dry farming [23]. At the top of the catchment, a gully has developed.

2.2. Methods. During the field work, we combined the experimental methods rill experiment and rainfall simulation with field mapping. As a geodetic control of the maps we used large scale aerial photographs, taken with our own equipment.
2.2.1. Rill Experiment. During the rill experiments, water was pumped into an existing erosion rill using a motordriven pump. For low flow experiments (LFEs) we used a constant discharge at the inlet of $9 \mathrm{~L} \mathrm{~min}^{-1}$ for 8 minutes. The total amount of water was $72 \mathrm{~L}$. In the high flow experiments (HFEs) we used a pump with a capacity between 250 and $330 \mathrm{~L} \mathrm{~min}^{-1}$. During 3 to 4 minutes we reached a water discharge of about $1000 \mathrm{~L}$. The mobilisation of sediments due to turbulences of water at the inlet of the measuring channel was suppressed by a special inlet construction.

Each rill experiment consisted of two runs. In the first run the rill was tested under field (dry) conditions and in the second run, about 15 min later, the same rill was tested under wet conditions. The flow velocity within the rill was measured by recording the travel times of the waterfront and of two applied colour tracers. In the LFEs, the colour tracers were used after the flow stabilisation ( 3 and 6 minutes) and in the HFEs after 1 and 2 minutes. Accordingly, three velocity curves were recorded and changes in flow dynamics can be detected. The used colour tracers were the food colourings $\mathrm{E}$ 124 (red) and E 13 (blue).

The rill's slope was measured using a spring bow of $1 \mathrm{~m}$ range with a digital spirit level. It has to be considered that slope measuring provided only average slopes for each meter of the rill length, so steps or knickpoints in the rill were not captured. However, the position of each step or knick-point and also the heights were separately recorded.

At each of the three measuring points (MP) along the rill, four water samples were taken: the first directly when the waterfront has reached the sampling point, the second $30 \mathrm{sec}$ later, the third after $90 \mathrm{sec}$, and the fourth $150 \mathrm{sec}$ after the arrival of the waterfront. The sediment concentration of each sample was determined by filtration in the laboratory $[24,25]$.

At each MP, the rill cross-section was measured by means of a yardstick (LFEs) or a laser rangefinder (HFEs). The distance between ground level and sensor, respectively, and rill bottom was measured in $0.02 \mathrm{~m}$ steps. This method allowed an accurate calculation of the rill's cross section area and also an estimation of the rills' volume at the MP.

The water height was measured simultaneously with the time of sampling by means of a yardstick in the LFEs or continuously by ultrasonic sensors (HFEs) at each measuring point.

2.2.2. Rainfall Simulations. The test plot was circular, with a diameter of $60 \mathrm{~cm}$ and an area of $0.28 \mathrm{~m}^{2}$. It was delimited by a steel ring of $7 \mathrm{~cm}$ height, which was introduced into the soil for at least $3 \mathrm{~cm}$. The outlet was $\mathrm{V}$-shaped and was placed at the deepest point of the plot at surface level. The commercial full cone nozzle (Lechler 460.608) was fed with a pressure of about $40 \mathrm{kPa}(0.4$ bars $)$ at a height of $2 \mathrm{~m}$. The water flow was regulated by a flow meter (Type KSK1200 HIG 100) positioned on a separate pole in $1.5 \mathrm{~m}$ height. The resulting rainfall intensity was maintained throughout the experiments at around $40 \mathrm{~mm} \mathrm{~h}^{-1}$, which is considered to be mean thunderstorm rainfall intensity with a return period 


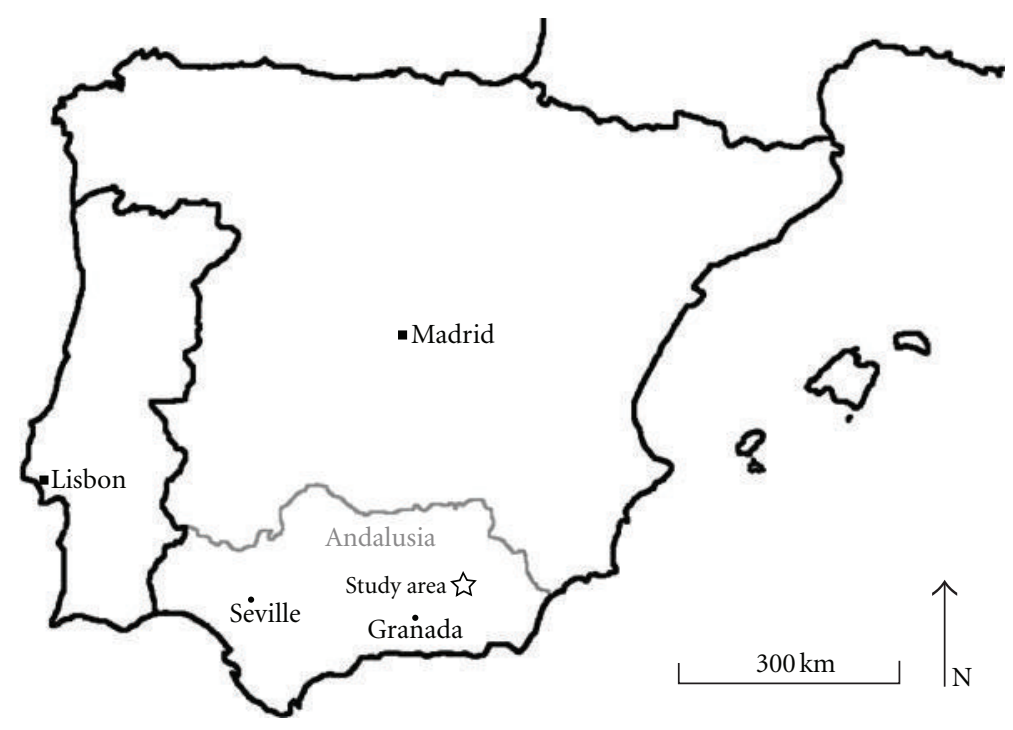

Figure 1: Test site in Andalusia (UTM: 509864 E-4154369 N).

TABLE 1: Setup parameters of the tested rills.

\begin{tabular}{lccccccc}
\hline Experiment & Rill & $\begin{array}{c}\text { Inflow intensity } \\
\left(\mathrm{L} \mathrm{min}^{-1}\right)\end{array}$ & $\begin{array}{c}\text { Inflow duration } \\
(\mathrm{min})\end{array}$ & $\begin{array}{c}\text { Catchment area } \\
\left(\mathrm{m}^{2}\right)\end{array}$ & $\begin{array}{c}\text { Tested rill length } \\
(\mathrm{m})\end{array}$ & $\begin{array}{c}\text { Estimated rill width } \\
(\mathrm{m})\end{array}$ & $\begin{array}{c}\text { Rill area } \\
\left(\mathrm{m}^{2}\right)\end{array}$ \\
\hline RE1_2008 & 1 & 9 & 8 & 415 & 15 & 6 \\
RE2_2008 & 2 & 9 & 8 & 203 & 21 & 0.4 & 0.4 \\
RE3_2008 & 3 & 9 & 8 & 579 & 15 & 0.5 & 7.5 \\
\hline RE4_2009 & 1 & 250 & 4 & 415 & 16 & 0.4 \\
RE5_2009 & 4 & 250 & 4 & 187 & 17 & 6.4 \\
RE6_2009 & 5 & 330 & 3 & 1641 & 21 & 6.4 \\
RE7_2009 & 1 & 250 & 4 & 415 & 16 & 6.4 & 6.1 \\
\hline
\end{tabular}

of about 2 years [26]. The complete runoff was collected and runoff and soil detachment was determined gravimetrically. $[23,27-30]$. The standard deviation of the rainfall intensity is $<5 \%$ [28].

Plot surface parameters were rock fragment cover, separated in embedded and overlying, vegetation cover, bare soil area, separated in crusted and uncrusted, and finally the slope of the plot. These parameters were optically estimated in the field and validated again with the help of digital photographs taken from every plot and preferably taken at an angle of $90^{\circ}$ to the plot surface. The slope was measured by a clinometer.

For comparing the variability of the different parameters, we calculated the average of the relative measurement errors (RME) following the DIN 1319-1 [31]. This error is defined as

$$
f=\frac{\left|x_{a}-x_{r}\right|}{x_{r}} * 100
$$

where $x_{a}$ are the measured values and $x_{r}$ are "correct" values; we used the mean of the measured values as $x_{r}$. This value describes the deviation of each single experiment from the mean of all experiments.
2.2.3. Small Format Aerial Photography (SFAP). The photos were taken using three different camera carriers depending on the wind conditions, requested flight level (photographed area) and available manpower: a hot air blimp, a kite, or an unmanned aerial vehicle (UAV). A detailed description of the camera carriers and aerial photography in general is to be found in Aber et al. [32]; the hot air blimp is also described in Ries and Marzolff [33].

The first used camera was a Canon 350D with a Canon EF-S 20 mm objective, the maximum solution of the photos is $8 \mathrm{MP}$, and the resulting stereoscopic images show a ground resolution between 0.5 and $11 \mathrm{~cm}$, depending on the flying height.

The second used camera was a Nikon Coolpix S6000 digital compact camera with a maximum solution of $14.48 \mathrm{MP}$. The zoom objective has an aperture angle dynamic between 28 and $144 \mathrm{~mm}$ and a light intensity between 2.8 and 5.6.

Aerial photographs were used during field work as a basis for the mapping and the classification in "vegetation areas" and "no vegetation areas."

2.2.4. Field Mapping and GIS Analysis. The field mapping based on the self-made aerial photographs should deliver 


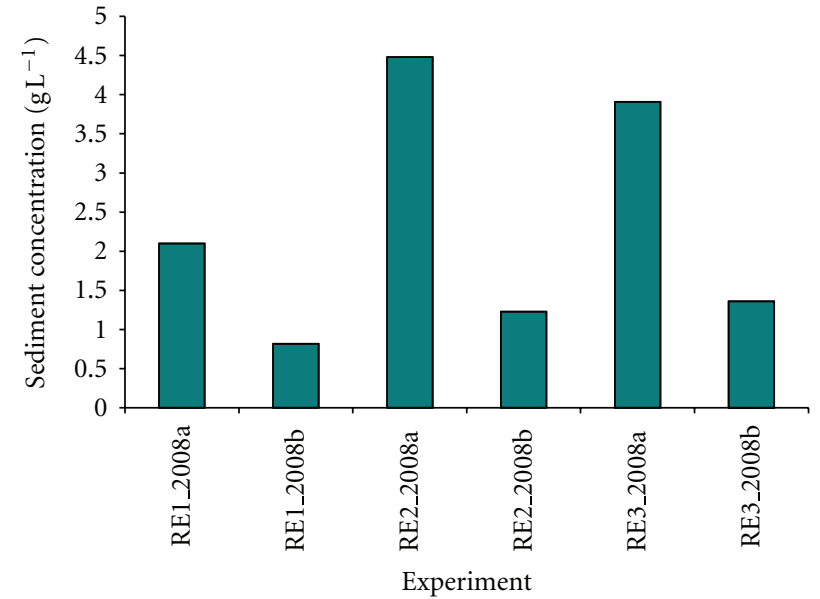

(a)

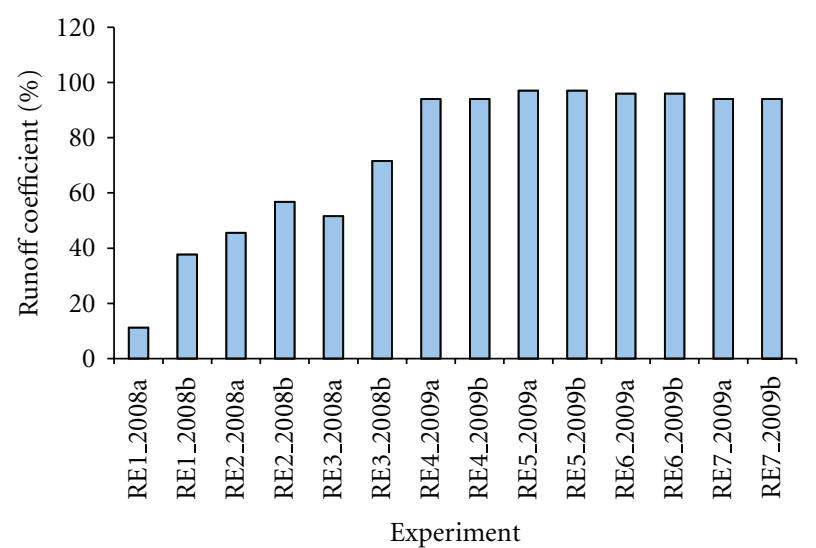

(c)

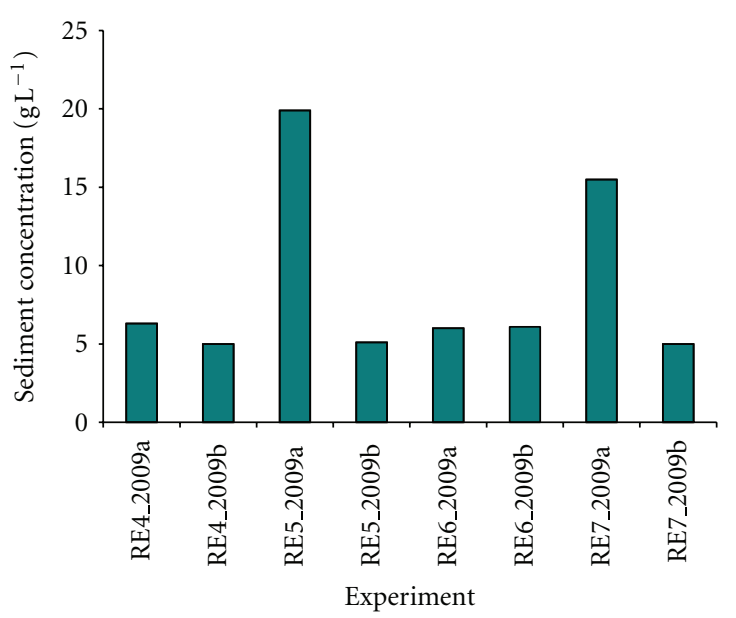

(b)

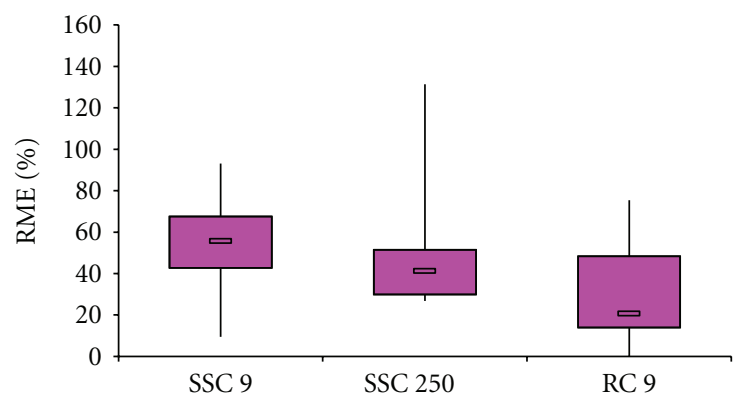

(d)

FIGURE 2: Results of the rill experiments: sediment concentrations of the 6 runs of the 3 rill experiments with an inflow intensity of 9 L min ${ }^{-1}$ (a), sediment concentrations of the 8 runs of the 4 rill experiments with an inflow intensity higher than $250 \mathrm{~L} \mathrm{~min}^{-1}$ (b), runoff coefficients of all rill experiments (c), relative measurements errors of the sediment concentrations (separated in experiments with an inflow intensity of $9 \mathrm{~L} \mathrm{~min}^{-1}$ and an inflow intensity higher than $250 \mathrm{~L} \mathrm{~min}^{-1}$ ), and the runoff coefficients (d).

information about the spatial distribution of linear erosion forms, the catchment areas of these forms, and a total rill length on the test site. With this information, different parameters can be calculated.

The total rill area is calculated as follows:

$$
A_{R}=W_{R} * L_{R}
$$

where $A_{R}$ is the total rill area $\left[\mathrm{m}^{2}\right], W_{R}$ is the estimated average rill width [m], and $L_{R}$ is the total rill length in the test site $[\mathrm{m}]$.

The rill density is calculated using the following equation:

$$
D_{R}=\frac{L_{R}}{A_{T}}
$$

where $D_{R}$ is the rill density $\left[\mathrm{m} \mathrm{ha}^{-1}\right], L_{R}$ is the total rill length in the test site [m], and $A_{T}$ is the test site area [ha].
The rill drainage index is calculated as follows:

$$
I_{R}=\frac{C_{R}}{A_{T}},
$$

where $I_{R}$ is the rill drainage index [ha ha- $\left.{ }^{-1}\right], C_{R}$ is the total area of all rill catchments [ha], and $A_{T}$ is the test site area [ha].

2.2.5. Classification of the Aerial Photographs. In order to obtain spatial information about the different land cover types and distribution, a classification of digital UAV imagery has been performed. First, an unsupervised classification was done for identifying the classes that can be statistically distinguished. As a result, only three classes could be distinguished, that is, "vegetation," "no vegetation/soill" and "shadow." A drawback of classifying UAV imagery was the fact that for such a large area, multiple flights were needed to cover the whole site. This led to a change of the illumination conditions 

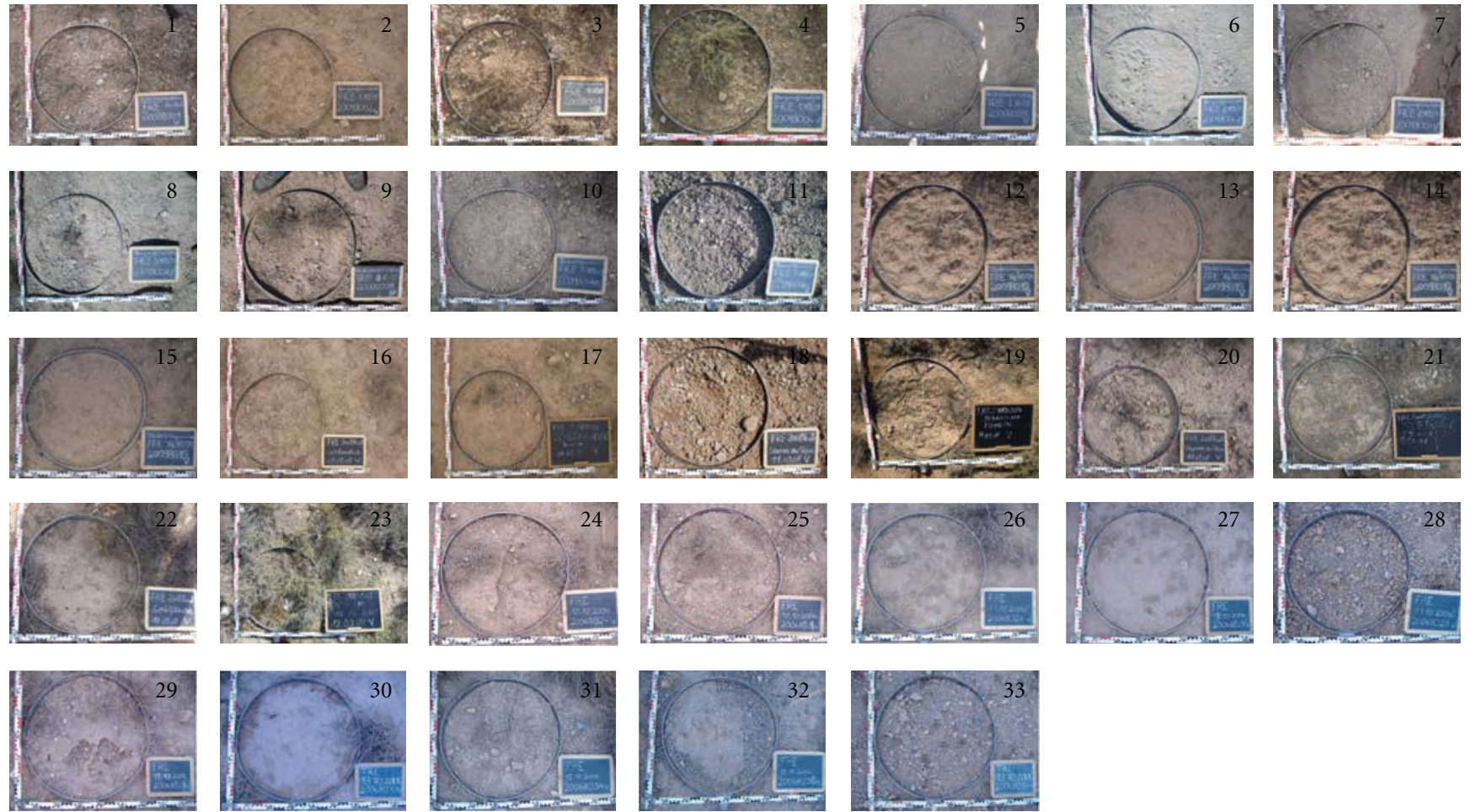

FIGURE 3: Surfaces of the used rainfall simulation plots.

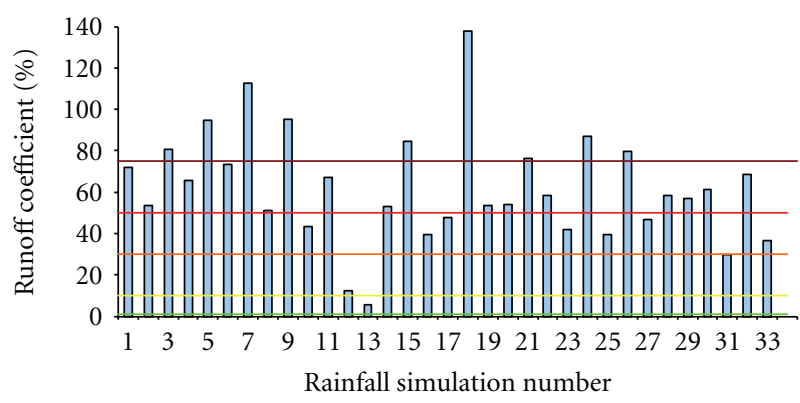

(a)

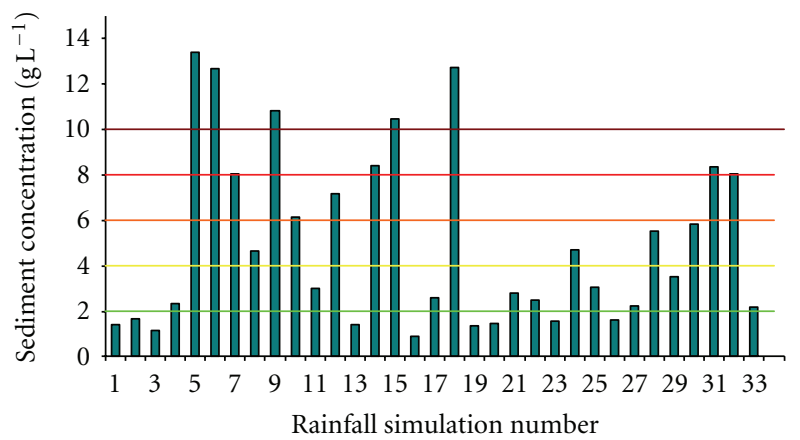

(c)

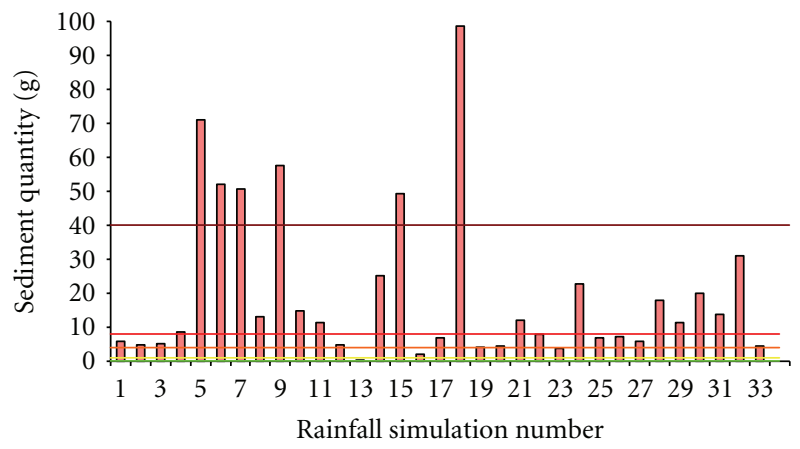

(b)

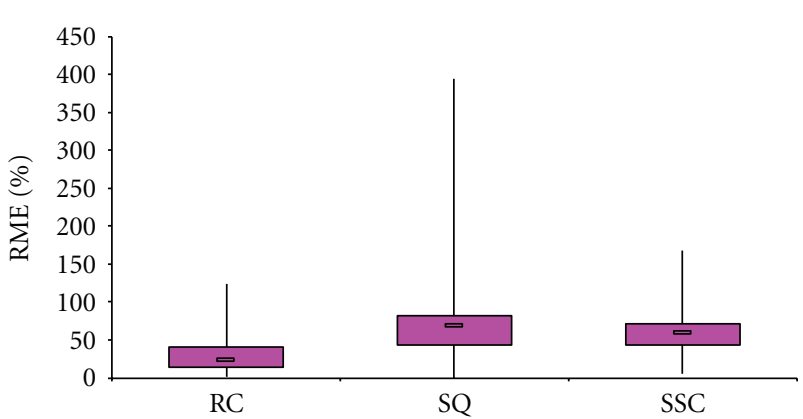

(d)

FIGURE 4: Results of the rainfall simulations: runoff coefficients (a), sediment quantities (b), and sediment concentrations (c). The limits between extremely high, very high, high, middle, low, and very low are marked. (d) Relative Measuring errors of the runoff coefficients (RC), the sediment quantities (SQ), and the sediment concentrations (SSC) of the rainfall simulations. 


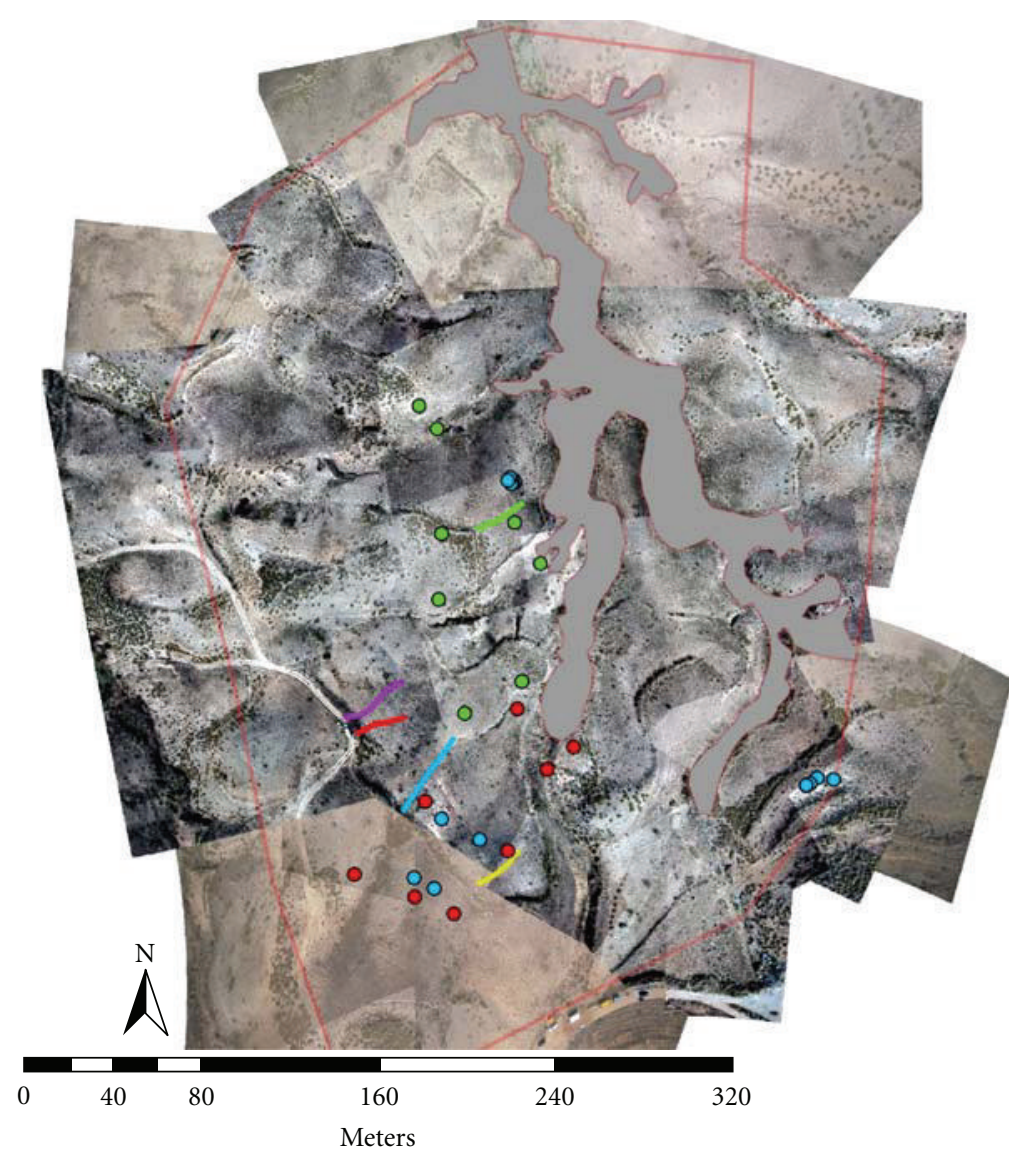

\begin{tabular}{|c|c|}
\hline \multicolumn{2}{|c|}{ Rainfall simulations } \\
\hline$\circ$ & 2009 \\
\hline$\bullet$ & 2008 \\
\hline$\bigcirc$ & 2006 \\
\hline
\end{tabular}
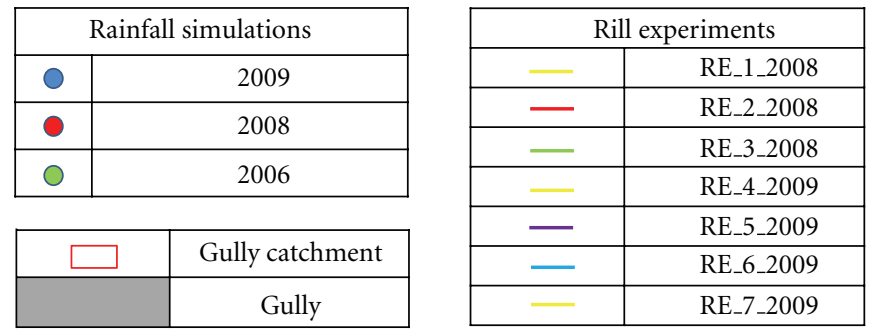

FIGURE 5: Positions of the rainfall simulations and the rill experiments.

for the different flights' images. Considering these facts, every tile of the mosaic needed to be classified individually. Using manually digitised training areas, the maximum likelihood classifier was chosen. After classification of every single tile, a mosaic was calculated.

\section{Results and Interpretation}

3.1. Rill Experiments. The rill experiments were accomplished in five different rills; one rill was tested three times, once in a LFE and two times in a HFE. The catchment areas of the tested rills were between 190 and $1600 \mathrm{~m}^{2}$; the tested rill parts showed lengths between 15 and $21 \mathrm{~m}$ and widths between 0.4 and $2.1 \mathrm{~m}$, resulting in rill areas between 6 and $44 \mathrm{~m}^{2}$. These values are summarised in Table 1 .

Figure 2 shows the results of the rill experiments. The sediment concentrations in the rill experiments with an inflow intensity of $9 \mathrm{~L} \mathrm{~min}^{-1}$ showed a data range between 0.8 (RE1_2008b) and $4.5 \mathrm{gL}^{-1}$ (RE2_2008a); the average sediment concentration was $2.3 \mathrm{~g} \mathrm{~L}^{-1}$. The rill experiments with an inflow intensity higher than $250 \mathrm{~L} \mathrm{~min}^{-1}$ showed sediment concentrations between 5 (RE4_2009b, RE5_2009b and RE7_2009b) and $20 \mathrm{gL}^{-1}$ (RE5_2009a); the average sediment concentration in these experiments was $8.6 \mathrm{~g} \mathrm{~L}^{-1}$, that means about 3.5 times higher than in the experiments with an inflow intensity of $9 \mathrm{~L} \mathrm{~min}^{-1}$. The runoff coefficients RCs showed a data range between 11 and around 95\%. In the experiments with an inflow quantity of $1000 \mathrm{~L}$ per run, nearly the complete water amount reached the end of the tested rill part. Using the RC and the flow length of the LFEs, we could calculate an average infiltration rate in $\mathrm{L} \mathrm{m}^{-1}$. This value was used to calculate the $\mathrm{RC}$ of the HFEs. The percentages of infiltrated water in the HFEs were between $3 \%$ and $6 \%$ so we used RCs between $94 \%$ and 


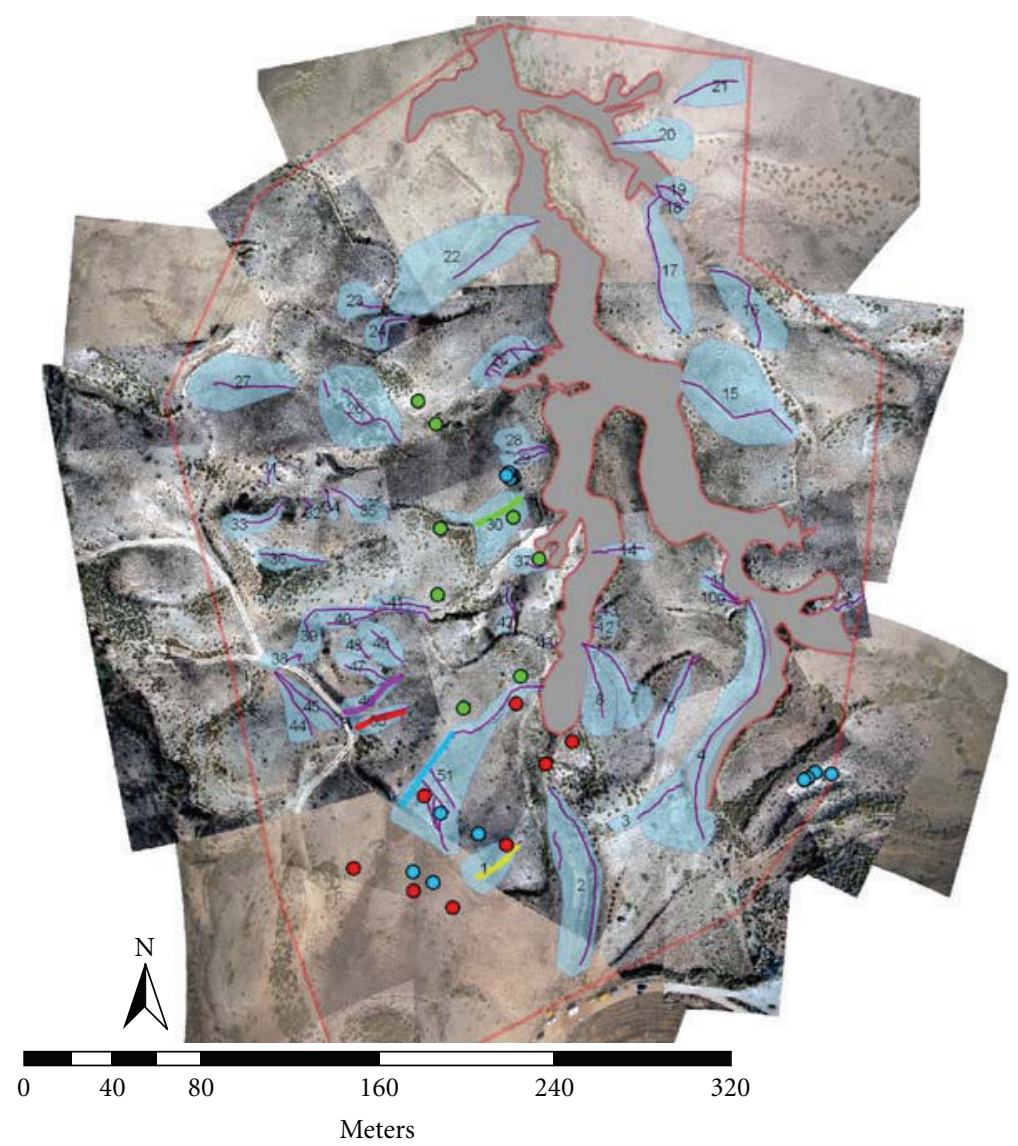

\begin{tabular}{|c|c|c|c|}
\hline \multicolumn{2}{|c|}{ Rainfall simulations } & \multicolumn{2}{|c|}{ Rill experiments } \\
\hline 0 & 2009 & - & RE_1_2008 \\
\hline 웅 & 2008 & - & RE_2_2008 \\
\hline 0 & 2006 & - & RE_3_2008 \\
\hline- & Rills & 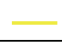 & RE_4_2009 \\
\hline$\square$ & Rill catchment & - & RE_5_2009 \\
\hline \multirow[t]{2}{*}{$\square$} & Gully catchment & 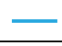 & RE_6_2009 \\
\hline & Gully & 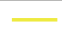 & RE_7_2009 \\
\hline
\end{tabular}

Figure 6: Additionally, mapped rills and their catchments.

97\%. These values are summarised in Table 2. The RMEs describe the variations between the single experiments and an average value. Most RMEs in the $9 \mathrm{~L} \mathrm{~min}^{-1}$ _experiments ranged between 67.5 (75\% quartile) and $42.8 \%(25 \%$ quartile), in the $250 \mathrm{~L} \mathrm{~min}^{-1}$ —experiments most RMEs were between 51.3 and 29.9\%. The highest RMEs were 93.1 and $131.4 \%$; the lowest values were 9.5 and $26.7 \%$; the medians were 55.8 and $41.3 \%$. The RCs showed lower variations than the sediment concentrations; most RMEs were between 48.3 and $13.9 \%$, the maximum value was $75.4 \%$, the minimum $0.3 \%$, and the median $20.8 \%$. The reason for the higher variations in sediment concentrations was "special events" such as bank failure and headcut retreat. Such processes increased the sediment concentration for a certain time period while the runoff stayed about constant.
3.2. Rainfall Simulations. In this study, the results of 33 rainfall experiments were used; the plots of all simulations are shown in Figure 3. In most cases, the rock fragments were embedded into the soil surface and the bare soil areas were crusted. Only in some special cases, for example, after a mechanical disturbance (goat trampling) and the resulting destruction of the crusts, the rock fragments were overlying. Most test plots showed a sparse vegetation cover and showed either a crusted soil surface or a cover with embedded rock fragments. Rainfall experiment 23 showed a dense vegetation cover; plots with mechanical treatment are 5-7 and 12-15. The influence of these parameters on runoff and erosion is discussed in Ries et al. [27] and Ries and Marzolff [33] for example. The percentages of the different surface parameters and the slope values of the different plots are summarised in Table 3. 


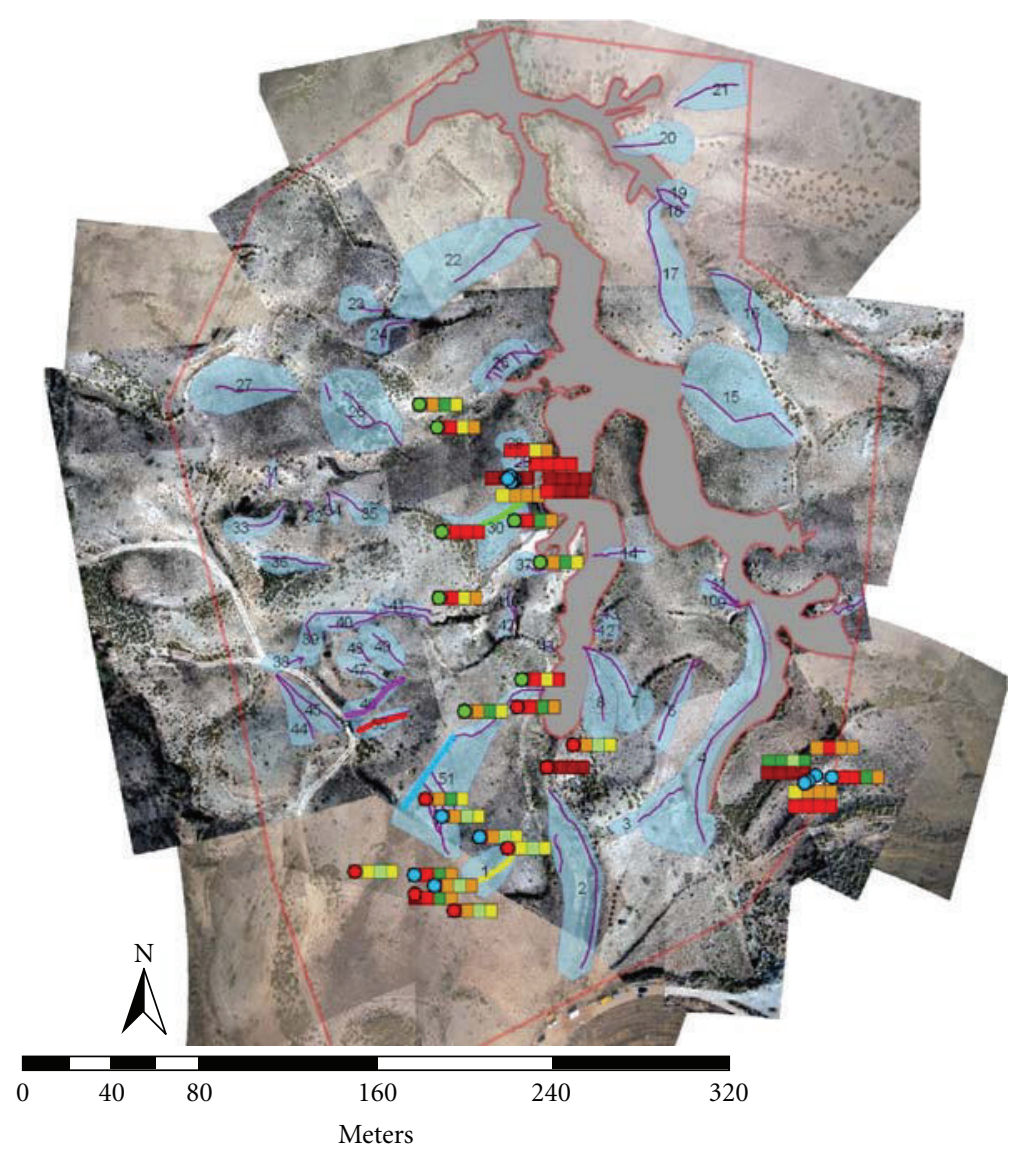

\begin{tabular}{|c|c|}
\hline \multicolumn{2}{|c|}{ Rainfall simulations } \\
\hline$\bigcirc$ & 2009 \\
\hline$\bigcirc$ & 2008 \\
\hline$\bigcirc$ & 2006 \\
\hline
\end{tabular}

\begin{tabular}{|l|c|c|}
\hline \multicolumn{2}{|c|}{ Classification } \\
\hline RC & SQ & SSC \\
\hline & \multicolumn{2}{|c|}{ Very low } \\
\hline & \multicolumn{2}{|c|}{ Low } \\
\hline & \multicolumn{2}{|c|}{ Middle } \\
\hline & \multicolumn{2}{|c|}{ High } \\
\hline & \multicolumn{2}{|c|}{ Very high } \\
\hline \multicolumn{2}{|c|}{ Extreme high } \\
\hline
\end{tabular}

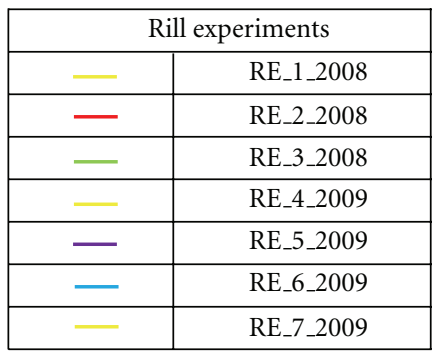

\begin{tabular}{|c|c|}
\hline- & Rills \\
\hline$\square$ & Rill catchment \\
\hline$\square$ & Gully catchment \\
\hline & Gully \\
\hline
\end{tabular}

Figure 7: Additionally, classification of runoff coefficient, sediment quantity, sediment concentration, and average assessment of the rainfall simulations.

The runoff coefficients, the amounts of eroded material, and the sediment concentration of the experiments were classified in 6 classes from very low (class 0 ) to extreme high (class 5) as shown in Table 4. Each class was symbolised by a box in a certain colour in Figure 7. The first box represented the runoff coefficient, the second the sediment quantity, and the third the sediment concentration. In the fourth box, the average class value from these three parameters was calculated. These values describe the hazard class of the tested plot against the called parameters. The class limits for runoff coefficient and sediment quantity were defined on the basis of the experience from about 400 rainfall simulations of the working group in semi-arid landscapes in North Africa and Spain during the past 16 years (e.g., $[23,27,34]$ ). For the definition of the sediment concentration class limits, we did not divide the sediment quantity and the runoff quantity, we defined other limits. The reason for this decision was, that in the other case, that nearly all rainfall simulations would show "very high" or even "extreme high" sediment concentrations even in cases of low sediment quantities (and low runoff 


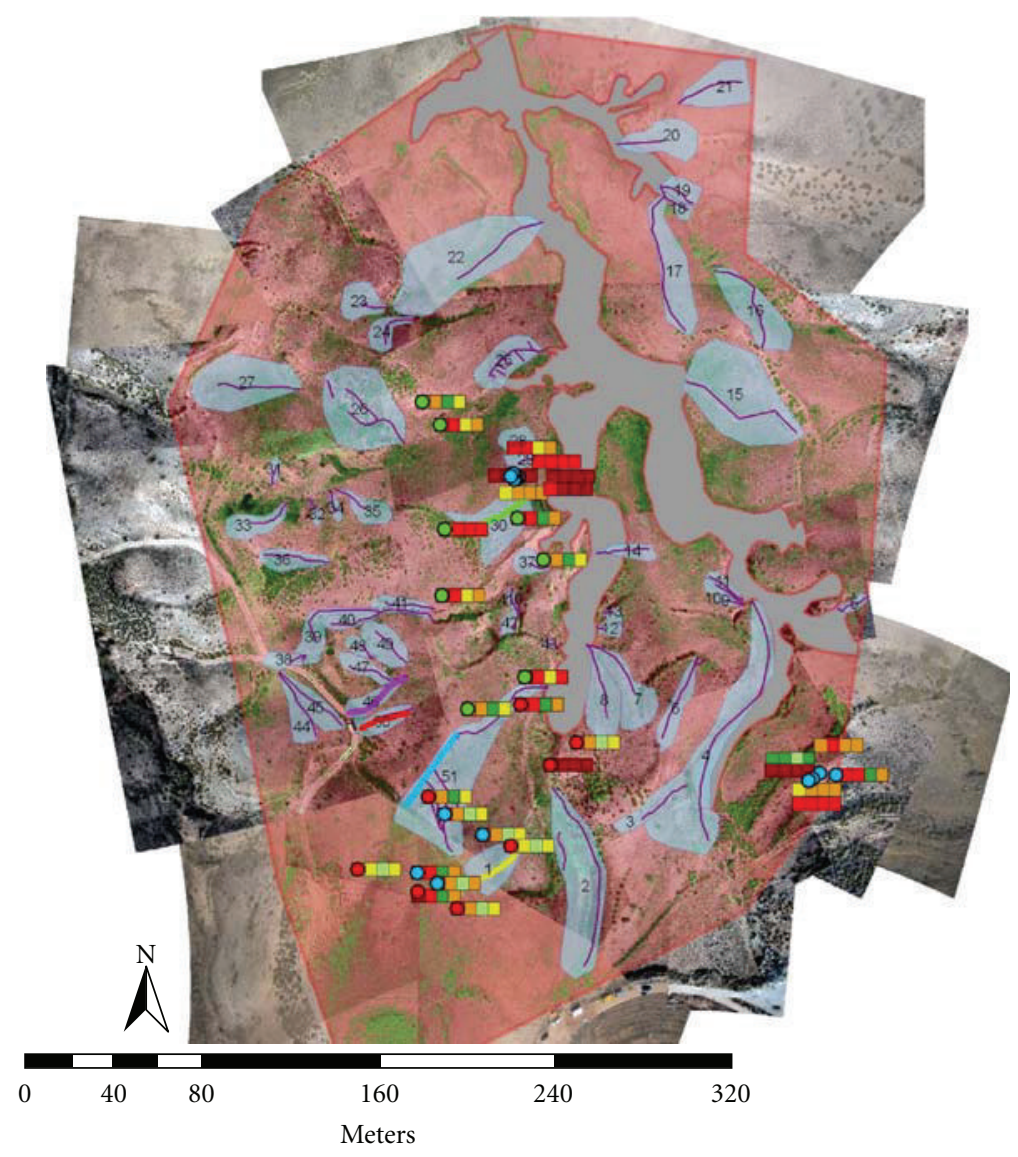

\begin{tabular}{|c|c|}
\hline \multicolumn{2}{|c|}{ Rainfall simulations } \\
\hline$\bigcirc$ & 2009 \\
\hline$\bullet$ & 2008 \\
\hline$\bigcirc$ & 2006 \\
\hline
\end{tabular}

\begin{tabular}{|c|c|c|}
\hline \multicolumn{3}{|c|}{ Classification } \\
\hline RC & SQ & SSC $\quad$ AV. \\
\hline & \multicolumn{2}{|c|}{ Very low } \\
\hline & \multicolumn{2}{|c|}{ Low } \\
\hline & \multicolumn{2}{|c|}{ Middle } \\
\hline & \multicolumn{2}{|c|}{ High } \\
\hline & \multicolumn{2}{|c|}{ Very high } \\
\hline & \multicolumn{2}{|c|}{ Extreme high } \\
\hline
\end{tabular}

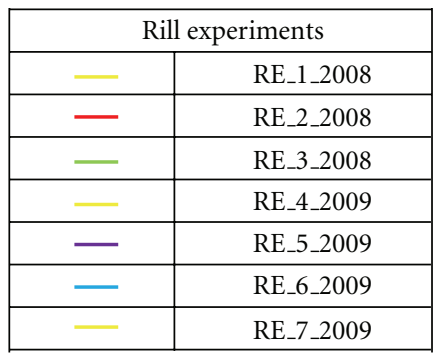

\begin{tabular}{|c|c|}
\hline & Vegetation \\
\hline & No vegetation \\
\hline
\end{tabular}

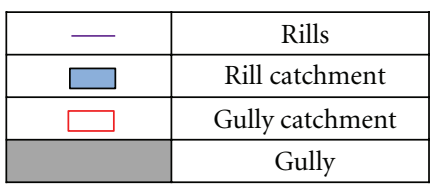

FIGURE 8: Additionally, soil surface coverage.

values). So we defined the limits "independent" of runoff coefficient and sediment quantity.

Regarding runoff coefficients (Figure 4(a)), a wide range from $5.6 \%$ to $100 \%$ could be observed. In the two cases the maximum RC of $100 \%$ was exceeded with values of $112.6 \%$ and $138 \%$ due to seepage of water from outside the plot ring. We still did not omit them because $91 \%$ of the rainfall simulation experiments showed high $(21 \%)$, very high $(42 \%)$, or extreme high $(27 \%)$ runoff coefficients. Only $9 \%$ showed middle $(6 \%)$ or low (3\%) values and no RC was very low.
Also $91 \%$ of the sediment quantity values were high (33\%), very high $(39 \%)$, or extreme high $(18 \%)$ and also only $9 \%$ showed middle $(6 \%)$ or low $(3 \%)$ values (Figure $4(\mathrm{~b})$ ). The range of sediment quantity was between $0.4 \mathrm{~g}$ and $98.5 \mathrm{~g}$.

Sediment concentrations of the rainfall simulation experiments ranged between $0.9 \mathrm{~g} \mathrm{~L}^{-1}$ and $13.4 \mathrm{~g} \mathrm{~L}^{-1}$ (Figure 4(c)). $33 \%$ of these values were high $(9 \%)$, very high $(9 \%)$, and extreme (15\%). $67 \%$ were middle (12\%), low (27\%), and very low $(27 \%)$.

Most of the RMEs were between 13.5 (25\% quartile) and $40.7 \%$ ( $75 \%$ quartile) for the runoff coefficients, between 
TABLE 2: Sediment concentrations and runoff coefficients of the rill experiments.

\begin{tabular}{lccc}
\hline Experiment & Rill & $\begin{array}{c}\text { Sediment concentration } \\
\left(\mathrm{g} \mathrm{L}^{-1}\right)\end{array}$ & $\begin{array}{c}\text { Runoff coefficient } \\
(\%)\end{array}$ \\
\hline RE1_2008a & 1 & 2.10 & 11.27 \\
RE1_2008b & & 0.82 & 37.75 \\
RE2_2008a & 2 & 4.48 & 45.61 \\
RE2_2008b & & 1.23 & 56.78 \\
RE3_2008a & 3 & 3.91 & 51.56 \\
RE3_2008b & & 1.36 & 71.54 \\
RE4_2009a & 1 & 6.30 & 94.00 \\
RE4_2009b & & 5.00 & 94.00 \\
RE5_2009a & 4 & 19.90 & 97.00 \\
RE5_2009b & & 5.10 & 97.00 \\
RE6_2009a & 5 & 6.00 & 96.00 \\
RE6_2009b & & 6.10 & 96.00 \\
RE7_2009a & 1 & 15.50 & 94.00 \\
RE7_2009b & & 5.00 & 94.00 \\
\hline
\end{tabular}

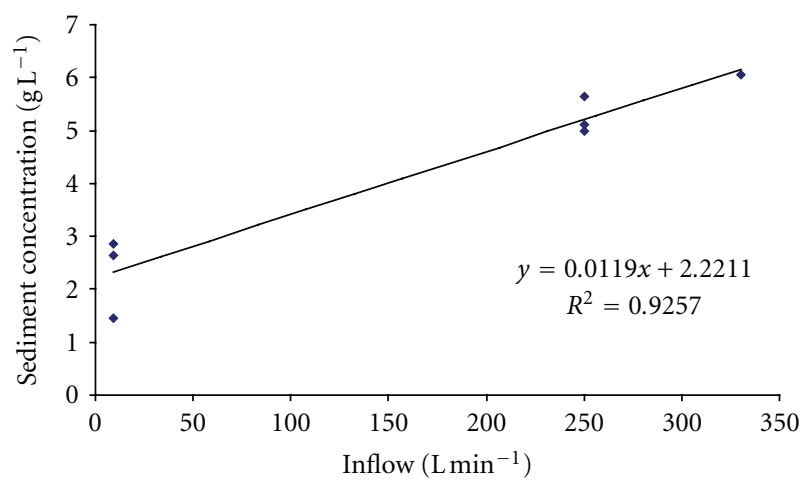

FIGURE 9: Relationship between the inflow intensity and the sediment concentration in the rill experiments.

43.4 and $81.8 \%$ for the sediment quantities, and between 43.4 and 71.8 for the sediment concentrations. The sediment quantity showed the highest maximum RME (394.7\%) and the highest median RME (70.4\%). The runoff values generally showed lower RME values than the erosion parameters, suggesting that the single values showed lower differences from an average value.

Regarding runoff coefficient classes, sediment quantity classes and sediment concentration classes that separated following the 3 groups (1) with mechanical treatment, (2) without mechanical treatment, and (3) high vegetation cover, a clear statement could be made: plots with a vegetation cover of maximal about $1 / 3$ (highest value in these groups: $36 \%)$ and without mechanical treatment showed average class values of 3.9 (very high) for runoff coefficient, 3.6 (very high) for sediment quantity, and 1.5 (low-middle) for sediment concentration (Table 5). Although absolute values
TABLE 3: Plot parameters and results of the 33 rainfall simulations: $\mathrm{RFC}_{\mathrm{e}}$ : rock fragment cover embedded, VC: vegetation cover, $\mathrm{BS}_{\mathrm{c}}$ : bare soil crusted, $\mathrm{RFC}_{\mathrm{o}}$ : rock fragment cover overlying, $\mathrm{BS}_{\mathrm{u}}$ : bare soil uncrusted, RC: runoff coefficient, SQ: sediment quantity, SSC: sediment concentration.

\begin{tabular}{|c|c|c|c|c|c|c|c|c|c|}
\hline Id & $\begin{array}{c}\mathrm{RFC}_{\mathrm{e}} \\
(\%)\end{array}$ & $\begin{array}{l}\text { VC } \\
(\%)\end{array}$ & $\begin{array}{l}\mathrm{BS}_{\mathrm{c}} \\
(\%)\end{array}$ & $\begin{array}{c}\mathrm{RFC}_{\mathrm{o}} \\
(\%)\end{array}$ & $\begin{array}{l}\mathrm{BS}_{\mathrm{u}} \\
(\%)\end{array}$ & $\begin{array}{c}\text { Slope } \\
\left({ }^{\circ}\right)\end{array}$ & $\begin{array}{l}\mathrm{RC} \\
(\%)\end{array}$ & $\begin{array}{l}\text { SQ } \\
\text { (g) }\end{array}$ & $\begin{array}{c}\mathrm{SSC} \\
\left(\mathrm{g} \mathrm{L}^{-1}\right)\end{array}$ \\
\hline 01 & 85 & 14 & 0 & 1 & 0 & 9 & 72.0 & 5.8 & 1.4 \\
\hline 02 & 1 & 1 & 98 & 0 & 0 & 11 & 53.3 & 4.9 & 1.7 \\
\hline 03 & 63 & 36 & 0 & 1 & 0 & 15 & 80.6 & 5.1 & 1.1 \\
\hline 04 & 6 & 35 & 58 & 1 & 0 & 13 & 65.9 & 8.7 & 2.4 \\
\hline 05 & 1 & 0 & 0 & 11 & 88 & 5 & 94.6 & 70.8 & 13.4 \\
\hline 06 & 1 & 0 & 0 & 13 & 86 & 5 & 73.5 & 52.2 & 12.7 \\
\hline 07 & 1 & 0 & 0 & 40 & 59 & 5 & 112.6 & 50.6 & 8.0 \\
\hline 08 & 25 & 6 & 68 & 1 & 0 & 9 & 51.0 & 13.2 & 4.6 \\
\hline 09 & 25 & 18 & 56 & 1 & 0 & 11 & 95.2 & 57.6 & 10.8 \\
\hline 10 & 91 & 0 & 8 & 1 & 0 & 15 & 43.2 & 14.9 & 6.2 \\
\hline 11 & 99 & 0 & 0 & 1 & 0 & 15 & 66.9 & 11.3 & 3.0 \\
\hline 12 & 1 & 3 & 0 & 4 & 92 & 15 & 12.2 & 4.9 & 7.2 \\
\hline 13 & 1 & 2 & 0 & 11 & 86 & 15 & 5.6 & 0.4 & 1.4 \\
\hline 14 & 1 & 3 & 0 & 4 & 92 & 15 & 53.1 & 25.0 & 8.4 \\
\hline 15 & 1 & 2 & 0 & 11 & 86 & 15 & 84.4 & 49.4 & 10.4 \\
\hline 16 & 18 & 0 & 81 & 1 & 0 & 12 & 39.5 & 1.9 & 0.9 \\
\hline 17 & 9 & 4 & 86 & 1 & 0 & 10 & 47.7 & 6.9 & 2.6 \\
\hline 18 & 96 & 0 & 3 & 1 & 0 & 16 & 138.0 & 98.5 & 12.7 \\
\hline 19 & 27 & 15 & 57 & 1 & 0 & 13 & 53.4 & 4.1 & 1.4 \\
\hline 20 & 60 & 1 & 38 & 1 & 0 & 11 & 54.1 & 4.5 & 1.5 \\
\hline 21 & 25 & 10 & 64 & 1 & 0 & 16 & 76.3 & 12.0 & 2.8 \\
\hline 22 & 1 & 17 & 82 & 0 & 0 & 6 & 58.2 & 8.1 & 2.5 \\
\hline 23 & 1 & 99 & 0 & 0 & 0 & 11 & 42.0 & 3.6 & 1.5 \\
\hline 24 & 22 & 17 & 60 & 1 & 0 & 6 & 86.8 & 22.9 & 4.7 \\
\hline 25 & 77 & 16 & 6 & 1 & 0 & 9 & 39.5 & 6.7 & 3.0 \\
\hline 26 & 1 & 19 & 80 & 0 & 0 & 4 & 79.8 & 7.2 & 1.6 \\
\hline 27 & 1 & 10 & 89 & 0 & 0 & 1.8 & 46.6 & 5.9 & 2.3 \\
\hline 28 & 96 & 2 & 1 & 1 & 0 & 19 & 58.2 & 17.9 & 5.5 \\
\hline 29 & 20 & 8 & 71 & 1 & 0 & 12.3 & 57.0 & 11.2 & 3.5 \\
\hline 30 & 0 & 6 & 94 & 0 & 0 & 2 & 61.3 & 20.0 & 5.8 \\
\hline 31 & 85 & 2 & 12 & 1 & 0 & 8 & 29.6 & 13.9 & 8.3 \\
\hline 32 & 52 & 0 & 47 & 1 & 0 & 7.5 & 68.4 & 30.9 & 8.1 \\
\hline 33 & 97 & 0 & 2 & 1 & 0 & 17 & 36.6 & 4.4 & 2.2 \\
\hline
\end{tabular}

showed differences, we found this an appropriate method for classification of subareas. The mechanical-treated plots representing goat trails also showed "very high" runoff coefficient and sediment quantity values (3.7 and 4.0). The sediment concentration showed in contrast to the other group also the class "very high" (3.7). That means that we defined for the test site area without vegetation and without goat trampling a very high RC (50.1-75\% runoff under a rainfall event of $40 \mathrm{~mm} \mathrm{~h}^{-1}$ for 30 minutes), a very high detachment rate $\left(8.1-40 \mathrm{~g}\right.$ per $0.28 \mathrm{~m}^{2}$, that means $29-143 \mathrm{~g} \mathrm{~m}^{-2}$ under the simulated rainfall event), and a middle sediment concentration $\left(4.1-6 \mathrm{~g} \mathrm{~L}^{-1}\right)$. The only 
TABLE 4: Classification of the rainfall simulations regarding runoff coefficient (RC), sediment quantity (SQ), and sediment concentration (SSC).

\begin{tabular}{|c|c|c|c|c|c|}
\hline \multicolumn{2}{|c|}{ Value } & $\mathrm{RC}(\%)$ & SQ (g) & $\operatorname{SSC}\left(\mathrm{g} \mathrm{L}^{-1}\right)$ & Colour \\
\hline Extreme high & 5 & $>75$ & $>40$ & $>10$ & \\
\hline Very high & 4 & $50.1-75$ & $8.1-40$ & $8.1-10$ & \\
\hline High & 3 & $30.1-50$ & $4.1-8$ & $6.1-8$ & \\
\hline Middle & 2 & $10.1-30$ & $1.1-4$ & $4.1-6$ & \\
\hline Low & 1 & $1-10$ & $0.1-1$ & $2-4$ & \\
\hline Very low & 0 & $<1$ & $<0.1$ & $<2$ & \\
\hline
\end{tabular}

Regarding Figures 7 and 8: First (left) box: RC class value; second box: SQ class value; third box: SSC class value; fourth (right) box: average class value.

rainfall simulation (Id 23) with high vegetation cover (99\%) showed lower class values, the RC was still "high" (30$50 \%$ ), the sediment loss could be classified as "middle" (4$\left.14 \mathrm{~g} \mathrm{~m}^{-2}\right)$, and the sediment concentration as "very low" $\left(<2 \mathrm{~g} \mathrm{~L}^{-1}\right)$.

3.3. Mapping, GIS Analyses and Aerial Photography. Figure 5 shows the positions of the 5 tested rills and the positions of 33 rainfall simulations. The different colours represent the year of accomplishment. Additionally, the outlines of the test site are marked. Figure 6 includes the mapped rills and their catchment areas; in Figure 7 the classification of the rainfall simulations is added. The classification system is presented in Table 4. In Figure 8, the soil coverage, divided in "vegetation" and "no vegetation," is presented additionally.

Table 6 lists the calculated test site parameters. The total rill length in the study area (10.01 ha) was $1694 \mathrm{~m}$. These rills drained an area of 1.98 ha, which was about $20 \%$ of the whole test area. The measured rills had an average width of $0.15 \mathrm{~m}$ (based on field mapping and SFAP), so there was an estimated rill area of about 0.025 ha $(0.25 \%$ of the study area). Accordingly, we could calculate the total interrill area at about 9.99 ha $(99.75 \%$ of the study area). The rill density was $169 \mathrm{~m} \mathrm{ha}^{-1}$. In the study area, a total trail length of about $365 \mathrm{~m}$ was mapped; the average width of these trails was about $1 \mathrm{~m}$. That means that an area of $365 \mathrm{~m}^{2}$ was covered with uncrusted soil and/or overlying rock fragments what makes up for only $0.5 \%$ of the nonvegetated area.

\section{Combination of the Results and Discussion}

To compare both, the results of the rill experiments and the rainfall simulations, we wanted to calculate the inflow intensity which would reach the rill under a real rainfall event of $40 \mathrm{~mm} \mathrm{~h}^{-1}$, an event simulated in our rainfall experiments. From the inflow intensity we could estimate the average sediment concentration following Figure 9. In this figure, we ignored two peaks: In RE5_2009a was a technical problem in sampling and in RE7_2009a 600 goats were crossing the rill before the measurement, so the quantity of lost material was too high. We therefore assumed in both cases the same sediment concentration as measured in run $\mathrm{b}$ of the experiment.

The relationship between runoff and the sediment concentration gave a high significance $R^{2}$ in our experiments but the database is still too small for general statements of these correlations. So in this study we used the relationship only for this test site and only for an approximate estimation of the sediment concentration, caused by runoff of a $40 \mathrm{~mm} \mathrm{~h}^{-1}$ rainfall event. The relationship between runoff and sediment yield is to be found in several studies. Parsons et al. [35], for example, measured runoff and eroded material from 8 runoff plots during 10 natural storm events and described a clear correlation between runoff coefficient and the sediment yield.

A critical point in upscaling the results from rainfall simulator area to catchment area scale was the well-known scale problem [36]. The plot size used in the rainfall simulations $\left(0.28 \mathrm{~m}^{2}\right)$ is too small for rill initiation. On the other hand, only much longer plot or slope lengths can cause rill development and, in consequence, initiate soil loss processes and runoff change. An important condition for the initiation of soil erosion in general is exceeding a certain threshold determined by soil parameters, such as soil shear strength or critical shear stress, via hydraulic parameters (shear stress, unit length shear force, and stream power). Those values are used to calculate transport and detachment capacities. Soil erosion can occur as long as the transport or detachment rate does not exceed the transport or detachment capacity. Exceeding this threshold will cause sedimentation of the excess material (e.g., [37]). Different research groups defined different thresholds that separate the interrill erosion from the initiation of rill erosion. Emmett [38] found that flowing water on entirely flat surfaces runs partially in preferred runoff paths with higher flow velocity, runoff depth, and consequently with different erosional behaviour. Other research groups stated $2-3^{\circ}[39,40]$ or $3-$ $7^{\circ}[41]$ as critical slope for rill initiation. When we assume a critical slope of $3^{\circ}$, only two (6\%) of our rainfall plots showed lower values; 8 plots (24\%) showed slope values lower than $7^{\circ}$. That denotes that upscaling the results from the rainfall simulation plots to a greater area will underestimate the real erosion and runoff values. Another critical value for rill initiation is a Froude number between 2.4 and 3 [39] or $1+0.0035 * D$, where $D$ is the median of grain size in $\mu \mathrm{m}$ [42]. Giménez and Govers [43] and Giménez [44] assume that there is a threshold Froude number. In laboratory experiments, they found that the flow velocity in natural (rough) rills was independent of the slope angle because of a feedback between rill bed morphology and flow parameters. The frequency of macroroughness (steps, pools) increased 
TABLE 5: Class values separated following "crusted soil," "rock fragment cover embedded," and "rock fragment cover overlying."

\begin{tabular}{|c|c|c|c|c|}
\hline Rainfall Sim. Id & RC class & SQ class & SSC class & Average class \\
\hline \multicolumn{5}{|c|}{ Group 1: with mechanical treatment } \\
\hline 5 & 5 & 5 & 5 & 5 \\
\hline 6 & 4 & 5 & 5 & 5 \\
\hline 7 & 5 & 5 & 3 & 4 \\
\hline 12 & 2 & 3 & 4 & 3 \\
\hline 13 & 1 & 1 & 0 & 1 \\
\hline 14 & 4 & 4 & 4 & 4 \\
\hline 15 & 5 & 5 & 5 & 5 \\
\hline Average group 1 & 3.7 & 4.0 & 3.7 & 3.9 \\
\hline \multicolumn{5}{|c|}{ Group 2: without mechanical treatment } \\
\hline 1 & 4 & 3 & 0 & 2 \\
\hline 2 & 4 & 3 & 0 & 2 \\
\hline 3 & 5 & 3 & 0 & 3 \\
\hline 4 & 4 & 4 & 1 & 3 \\
\hline 8 & 4 & 4 & 2 & 3 \\
\hline 9 & 5 & 5 & 5 & 5 \\
\hline 10 & 3 & 4 & 3 & 3 \\
\hline 11 & 4 & 4 & 1 & 3 \\
\hline 18 & 5 & 5 & 5 & 5 \\
\hline 16 & 3 & 2 & 0 & 2 \\
\hline 17 & 3 & 3 & 1 & 2 \\
\hline 19 & 4 & 3 & 0 & 2 \\
\hline 20 & 4 & 3 & 0 & 2 \\
\hline 21 & 5 & 4 & 1 & 3 \\
\hline 22 & 4 & 4 & 1 & 3 \\
\hline 24 & 5 & 4 & 2 & 4 \\
\hline 25 & 3 & 3 & 1 & 2 \\
\hline 26 & 5 & 3 & 0 & 3 \\
\hline 27 & 3 & 3 & 1 & 2 \\
\hline 28 & 4 & 4 & 2 & 3 \\
\hline 29 & 4 & 4 & 1 & 3 \\
\hline 30 & 4 & 4 & 2 & 3 \\
\hline 31 & 2 & 4 & 4 & 3 \\
\hline 32 & 4 & 4 & 4 & 4 \\
\hline 33 & 3 & 3 & 1 & 2 \\
\hline Average group 2 & 3.9 & 3.6 & 1.5 & 2.9 \\
\hline \multicolumn{5}{|c|}{ Special group: vegetation cover } \\
\hline 23 & 3 & 2 & 0 & 2 \\
\hline
\end{tabular}

with slope and, as a consequence, an increase of the flow velocity was prevented. With increasing slope, the water accelerated until a Froude number between 1.3 and 1.7 was reached. At this point, an "hydraulic jump" occurred and a plungepool could develop [44, 45]. The Froude number of the runoff on our rainfall simulation plots was clearly below 1 , so the mentioned critical values were not reached. In contrast to the cited research groups, Torri et al. [46] and Merz and Bryan [47] stated that the Froude number was not applicable to discriminate between rill and interrill flow because runoff in rills was not implicit supercritical.
TABLE 6: Different test site parameters.

\begin{tabular}{lc}
\hline Parameter & Value \\
\hline Total rill length $L_{R}(\mathrm{~m})$ & 1694 \\
Area of the test site $A_{T}(\mathrm{ha})$ & 10.01 \\
Catchment area of all rills $C_{R}(\mathrm{ha})$ & 1.98 \\
Estimated average rill width $W_{R}(\mathrm{~m})$ & 0.15 \\
Total rill area $A_{R}(\mathrm{ha})$ & 0.025 \\
Interrill area $A_{I}(\mathrm{ha})$ & 9.99 \\
Rill amount on total test site $(\%)$ & 0.25 \\
Interrill amount on total test site $(\%)$ & 99.75 \\
Rill density $D_{R}(\mathrm{~m}$ ha & $-1)$ \\
Rill drainage index $I_{R}(\%)$ & 169 \\
Trail length $(\mathrm{m})$ & 20 \\
Trail area $\left(\mathrm{m}^{2}\right)$ & 365 \\
\hline
\end{tabular}

A third possible factor influencing the rill initiation is the runoff intensity. Loch and Donnollan [48] observed rill development on clay soils with a slope angle of $2.3^{\circ}$, where the runoff reached an intensity of 0.3 to $0.6 \mathrm{~L} \mathrm{sec}^{-1}$. Moss et al. [49] determined a value of $0.6 \mathrm{~L} \mathrm{sec}^{-1}$ on noncohesive quartz sand with a slope of $0.2-0.3^{\circ}$. Loch and Thomas [50] found much higher values: they determined minimum runoff intensities of more than $3 \mathrm{~L} \mathrm{sec}^{-1}$. In our rainfall experiments, $100 \%$ runoff was $5.6 \mathrm{~L} 30 \mathrm{~min}^{-1}$, that means an average value of $0.003 \mathrm{~L} \mathrm{sec}^{-1}$. In consequence to the reported critical runoff intensities of the research groups, none of our rainfall simulation plots was able to develop any rills. Merz [16] doubts the importance about the runoff as a significant value for rill initiation. In his studies, the runoff was measured at the lowermost part of a test plot. These values could not describe a reliable average of the hydraulic situation since the runoff was not constant over the whole plot. Merz [16] assumed that different critical runoff values in both studies are based on variations in cohesive forces of the substratum and other soil physical parameters. Therefore, the critical runoff should not be used as a confirmed parameter for rill development.

More detailed results of soil and water movement under defined conditions are listed below in Table 7. The conditions for the precipitation were $40 \mathrm{~mm} \mathrm{~h}^{-1}$ rainfall event within $30 \mathrm{~min}$. The field mapping provided size and position of catchments areas. The classification of the surface in "vegetation" and "no vegetation" was done by aerial images. We assumed that the complete runoff from "no vegetation" areas can reach the rills. Rainfall experiments of Cerdà [51] in southeast Spain on Stipa tenacissima areas showed that surface runoff and erosion were negligible in the tussock and quite high in bare areas. So we could calculate the rainfall quantity that reaches to uncovered surface areas of the rill catchments by multiplying the "no-vegetation" area in each catchment with $20\left(40 \mathrm{~mm} \mathrm{~h}^{-1}\right.$ but duration just $\left.30 \mathrm{~min}\right)$. The rainfall simulations were accomplished on areas with very low vegetation cover and the classification of the rainfall experiments showed a "very high" (class 4 ) runoff coefficient between $50 \%$ and $75 \%$, independent of the soil surface cover (crusted, overlying, or embedded rock fragments). Because 
TABLE 7: Runoff and erosion parameters of the rill catchments. The presented values based on the class limits.

\begin{tabular}{|c|c|c|c|c|c|c|c|c|}
\hline \multirow{2}{*}{ Id. } & \multicolumn{4}{|c|}{ Rill catchment } & \multicolumn{4}{|c|}{ Rill } \\
\hline & $\begin{array}{l}\text { Area } \\
\left(\mathrm{m}^{2}\right)\end{array}$ & $\begin{array}{c}\text { Vegetation area } \\
\left(\mathrm{m}^{2}\right)\end{array}$ & $\begin{array}{c}\text { No vegetation area } \\
\left(\mathrm{m}^{2}\right)\end{array}$ & $\begin{array}{l}\text { Runoff quantity } \\
\text { (L) }\end{array}$ & $\begin{array}{l}\text { Rill length } \\
\text { (m) }\end{array}$ & $\begin{array}{l}\text { Runoff intensity } \\
\left(\mathrm{L} \mathrm{min}^{-1}\right)\end{array}$ & $\begin{array}{c}\mathrm{SSC} \\
\left(\mathrm{g} \mathrm{L}^{-1}\right)\end{array}$ & $\begin{array}{c}\text { Erosion rate } \\
\left(\mathrm{g} \mathrm{m}^{-2}\right)\end{array}$ \\
\hline 1 & 415 & 89 & 326 & $3256-4884$ & 26 & $106-161$ & $3-4$ & $34-61$ \\
\hline 2 & 1346 & 477 & 869 & 8695-13042 & 106 & $281-426$ & $6-7$ & $54-107$ \\
\hline 3 & 87 & 3 & 84 & $843-1264$ & 26 & $26-40$ & $3-3$ & $23-38$ \\
\hline 4 & 1852 & 382 & 1470 & $14696-22044$ & 121 & $480-725$ & $8-11$ & $78-160$ \\
\hline 5 & 59 & 23 & 36 & $365-547$ & 16 & $11-17$ & $2-2$ & $21-34$ \\
\hline 6 & 280 & 17 & 263 & $2633-3950$ & 51 & $84-127$ & $3-4$ & $31-54$ \\
\hline 7 & 466 & 63 & 403 & 4033-6049 & 32 & 132-199 & $4-5$ & $37-68$ \\
\hline 8 & 448 & 64 & 384 & $3839-5759$ & 35 & $125-189$ & $4-4$ & $36-66$ \\
\hline 9 & 41 & 11 & 30 & $299-449$ & 10 & 9-14 & $2-2$ & $21-34$ \\
\hline 10 & 61 & 19 & 42 & $424-636$ & 16 & $13-20$ & $2-2$ & $21-35$ \\
\hline 11 & 66 & 25 & 41 & $407-610$ & 19 & $12-19$ & $2-2$ & $21-34$ \\
\hline 12 & 66 & 17 & 49 & $489-733$ & 4 & $16-24$ & $2-3$ & $24-37$ \\
\hline 13 & 43 & 32 & 11 & 110-166 & 5 & $3-5$ & $2-2$ & $20-32$ \\
\hline 14 & 133 & 21 & 112 & $1121-1682$ & 24 & $35-54$ & $3-3$ & $25-41$ \\
\hline 15 & 1616 & 393 & 1223 & $12235-18352$ & 60 & $403-607$ & $7-9$ & $69-140$ \\
\hline 16 & 622 & 231 & 391 & $3913-5870$ & 49 & 126-192 & $4-5$ & $36-66$ \\
\hline 17 & 692 & 41 & 651 & 6513-9770 & 67 & $212-320$ & $5-6$ & $46-89$ \\
\hline 18 & 81 & 30 & 51 & 513-770 & 18 & $16-24$ & $2-3$ & $22-35$ \\
\hline 19 & 155 & 17 & 138 & 1379-2068 & 17 & $45-68$ & $3-3$ & $27-44$ \\
\hline 20 & 443 & 11 & 432 & $4323-6484$ & 21 & $142-214$ & $4-5$ & $39-71$ \\
\hline 21 & 491 & 0 & 491 & $4909-7363$ & 31 & $161-243$ & $4-5$ & $41-76$ \\
\hline 22 & 1658 & 253 & 1405 & $14053-21079$ & 48 & 464-699 & $8-11$ & $77-157$ \\
\hline 23 & 255 & 33 & 222 & $2222-3333$ & 12 & $73-110$ & $3-4$ & $30-52$ \\
\hline 24 & 177 & 31 & 146 & $1460-2189$ & 22 & $47-71$ & $3-3$ & $27-45$ \\
\hline 25 & 408 & 63 & 345 & $3454-5182$ & 58 & 110-168 & $4-4$ & $34-62$ \\
\hline 26 & 1120 & 345 & 775 & $7752-11629$ & 62 & $253-382$ & $5-7$ & $51-100$ \\
\hline 27 & 916 & 232 & 684 & 6844-10267 & 38 & 225-339 & $5-6$ & $48-93$ \\
\hline 28 & 183 & 57 & 126 & $1265-1897$ & 15 & $41-62$ & $3-3$ & $26-44$ \\
\hline 29 & 109 & 28 & 81 & $811-1216$ & 17 & $26-39$ & $3-3$ & $24-39$ \\
\hline 30 & 579 & 92 & 487 & $4870-7305$ & 26 & $160-241$ & $4-5$ & $41-76$ \\
\hline 31 & 49 & 16 & 33 & $334-500$ & 8 & $10-16$ & $2-2$ & $22-35$ \\
\hline 32 & 37 & 10 & 27 & $268-402$ & 6 & $8-13$ & $2-2$ & $22-34$ \\
\hline 33 & 250 & 90 & 160 & 1598-2397 & 20 & $52-78$ & $3-3$ & $27-46$ \\
\hline 34 & 46 & 10 & 36 & $364-545$ & 10 & $11-17$ & $2-2$ & $22-35$ \\
\hline 35 & 195 & 67 & 128 & $1285-1927$ & 19 & $41-63$ & $3-3$ & $26-43$ \\
\hline 36 & 237 & 93 & 144 & $1444-2166$ & 30 & $46-70$ & $3-3$ & $26-44$ \\
\hline 37 & 151 & 15 & 136 & $1363-2045$ & 11 & $45-67$ & $3-3$ & $27-45$ \\
\hline 38 & 117 & 18 & 99 & $986-1479$ & 8 & $32-49$ & $3-3$ & $26-41$ \\
\hline 39 & 365 & 96 & 269 & $2689-4034$ & 73 & $84-128$ & $3-4$ & $30-54$ \\
\hline 40 & 128 & 30 & 98 & $978-1466$ & 24 & $31-47$ & $3-3$ & $24-40$ \\
\hline 41 & 132 & 26 & 106 & $1058-1587$ & 34 & $32-50$ & $3-3$ & $24-40$ \\
\hline 42 & 68 & 10 & 58 & 579-869 & 12 & $18-28$ & $2-3$ & $23-37$ \\
\hline 43 & 15 & 4 & 11 & 109-164 & 6 & $3-5$ & $2-2$ & $19-31$ \\
\hline 44 & 224 & 42 & 182 & $1824-2736$ & 34 & $58-88$ & $3-3$ & $28-48$ \\
\hline 45 & 259 & 80 & 179 & $1791-2686$ & 38 & $57-86$ & $3-3$ & $27-47$ \\
\hline 46 & 188 & 42 & 146 & $1456-2183$ & 33 & $46-70$ & $3-3$ & $26-44$ \\
\hline 47 & 171 & 26 & 145 & $1447-2171$ & 21 & $46-71$ & $3-3$ & $27-45$ \\
\hline 48 & 79 & 14 & 65 & 649-973 & 9 & $21-32$ & $2-3$ & $24-38$ \\
\hline
\end{tabular}


TABle 7: Continued.

\begin{tabular}{|c|c|c|c|c|c|c|c|c|}
\hline \multirow{2}{*}{ Id. } & \multicolumn{4}{|c|}{ Rill catchment } & \multicolumn{4}{|c|}{ Rill } \\
\hline & $\begin{array}{l}\text { Area } \\
\left(\mathrm{m}^{2}\right)\end{array}$ & $\begin{array}{l}\text { Vegetation area } \\
\qquad\left(\mathrm{m}^{2}\right)\end{array}$ & $\begin{array}{l}\text { No vegetation area } \\
\left(\mathrm{m}^{2}\right)\end{array}$ & $\begin{array}{l}\text { Runoff quantity } \\
\text { (L) }\end{array}$ & $\begin{array}{l}\text { Rill length } \\
\text { (m) }\end{array}$ & $\begin{array}{l}\text { Runoff intensity } \\
\qquad\left(\mathrm{L} \mathrm{min}^{-1}\right)\end{array}$ & $\begin{array}{c}\text { SSC } \\
\left(\mathrm{g} \mathrm{L}^{-1}\right)\end{array}$ & $\begin{array}{c}\text { Erosion rate } \\
\quad\left(\mathrm{g} \mathrm{m}^{-2}\right)\end{array}$ \\
\hline 49 & 297 & 44 & 253 & $2534-3801$ & 21 & $83-125$ & $3-4$ & $31-55$ \\
\hline 50 & 203 & 35 & 168 & $1675-2513$ & 26 & $54-82$ & $3-3$ & $27-47$ \\
\hline 51 & 1641 & 306 & 1335 & $13352-20028$ & 187 & $429-652$ & $7-10$ & $71-146$ \\
\hline 410 & 30 & 4 & 26 & $257-386$ & 12 & $8-12$ & $2-2$ & $20-33$ \\
\hline
\end{tabular}

TABle 8: Comparison of rill and interrill areas. The erosion values are only valid for the rill areas, not for the rill catchment areas (specific explanation in the text).

\begin{tabular}{lcc}
\hline & $\begin{array}{c}\text { Rills/rill } \\
\text { catchments }\end{array}$ & $\begin{array}{c}\text { Interrill area } \\
\text { without gully }\end{array}$ \\
\hline Area complete $\left(\mathrm{m}^{2}\right)$ & $254 / 19750$ & 100079 \\
Area, vegetation $\left(\mathrm{m}^{2}\right)$ & $\mathrm{X} / 4174$ & 21912 \\
Area, no vegetation $\left(\mathrm{m}^{2}\right)$ & $\mathrm{X} / 15576$ & 78167 \\
Erosion rate $\left(\mathrm{g} \mathrm{m}^{-2}\right)$ & $1685-3018 / \mathrm{X}$ & $29-143$ \\
Erosion quantity $(\mathrm{kg})$ & $425-762 / \mathrm{X}$ & $2267-11178$ \\
Runoff intensity $\left(\mathrm{m}^{3} \mathrm{~s}^{-1}\right)$ & $0.08-0.13 / \mathrm{X}$ & $0.43-0.65$ \\
Runoff intensity per $\mathrm{m}^{2}\left(\mathrm{~cm} \mathrm{~s}^{-1}\right)$ & $0.03-0.05 / \mathrm{X}$ & $0.0006-0.0008$ \\
\hline
\end{tabular}

of the range in the runoff classification, we also got a range in the runoff and erosion parameters in Table 7. We could calculate the runoff quantity and the runoff intensity. Based on the runoff values of our rill experiments, we assumed that there was an average infiltration rate of $2.5 \mathrm{~L} \mathrm{~m}^{-1}$ in the rill so we could calculate the water quantity and the runoff intensity which was able to cause erosion. Figure 7 shows the correlation between the runoff intensity and the sediment concentration calculated from the results of the rill experiments. Using the currently known runoff intensity in the rill and the equation in Figure 7, we could calculate the sediment concentrations in the rills. Runoff quantity, rill lengths, and the average rill widths were known, so we could calculate the absolute erosion quantity and the erosion rate per unit area.

It has to be considered that the rill catchments were only used to calculate the runoff for the rills, erosion only taking place directly in the rills. That means that the rill catchments were on the "rill site" regarding the runoff but on the "interrill site" concerning the erosion parameters. Table 8 summarises the results of Table 7: the complete interrill areas without gully covered $100079 \mathrm{~m}^{2} ; 19750 \mathrm{~m}^{2}$ of which were catchments for rills which covered $254 \mathrm{~m}^{2}$ resulting from the total rill length and an average rill width. $21912 \mathrm{~m}^{2}$ were covered with vegetation; $78167 \mathrm{~m}^{2}$ showed bare soil. The erosion rates in the rills reached values between 1685 and $3018 \mathrm{~g} \mathrm{~m}^{-2}$ (under a $40 \mathrm{~mm} \mathrm{~h}^{-1}$ rainfall event of $30 \mathrm{~min}$ ), whereas the soil loss in the interrill areas was only between 29 and $143 \mathrm{~g} \mathrm{~m}^{-2}$ (20-60 times less). This relationship is confirmed by Morgan [52], who stated that rill sediment transport exceeded interrill transport by a factor of 40 on an $11^{\circ}$ slope. Due to the much larger area of the interrill areas, the total soil loss quantity was about 5 to 15 times higher than in the rills. The runoff intensity of the water from the interrill area was about 5 times higher than the runoff intensity of the rill flow. Regarding the runoff intensity per square meter, the rills' value exceeded the interrills' value by the factor 50 .

One ignored point in our study is the gully in the test site. This is acceptable in so far as the gully is not active. An active gully would certainly raise the runoff and erosion values on the gully bottom.

We probably underestimated the rill erosion values: during a real rainfall event, the water would fill the rill from upstream and from both sides, whereas in the experiments, the water entered the rill at a single point. The measured sediment concentrations in the rills (maximum $19.9 \mathrm{~g} \mathrm{~L}-1$ in RE5_2009a) showed relatively low values. In the surrounding area of the presented test site, we still measured much higher sediment concentrations of up to $438 \mathrm{~g} \mathrm{~L}-1$ that caused by an inflow intensity of only $9 \mathrm{~L} \mathrm{min-1} \mathrm{[25].} \mathrm{This} \mathrm{means} \mathrm{that}$ the rill effectiveness could be even higher than the presented results implicate. Unfortunately, we do not (yet) have enough data of the surrounding test sites for a comparison of the different areas.

\section{Conclusions}

The aim of this study was to compare the effectiveness of rill and interrill areas concerning soil erosion on one abandoned land site in Andalusia. The results are only valid for the tested area; they cannot easily be adapted to other areas or used as general statement about the relation between rill and interrill erosion. We combined the results of rill experiments, rainfall simulations, field mapping, and small scale aerial photographs to get an idea about the dimension of the soil loss caused by rill and interrill flow. In our test site, the rills reached much higher erosion rates than the interrill erosion (20-60 times higher). Because of the much larger interrill area, the absolute erosion values of the interrill areas were 515 times higher than these of the rill area. The rills in our study area drained $19800 \mathrm{~m}^{2}$ of the $100079 \mathrm{~m}^{2}$ study area; this means that $0.25 \%$ of the study area were responsible for $20 \%$ of the area providing runoff. The results clearly proved the importance of the rills as sediment provider as well as runoff accumulator. The possible influence of the gully in our study area was ignored in this study, so we cannot state the possibly erosion-activating effect of our applied rainfall intensity of $40 \mathrm{~mm} \mathrm{~h}^{-1}$. We know about the problems and the limitations of upscaling experimental field assessments but as 
we only presented ranges or class limits, we assume that the results remain in realistic dimensions.

\section{Acknowledgments}

The research was supported by the "Internationales Graduiertenzentrum" of Trier University, by the Deutsche Forschungsgemeinschaft (DFG) Project nos. Ri 835/2 and Ri-835/6-1, and by the "Freundeskreis Trierer Universität e.V." Additionally, we thank all participants of the field trips to Andalusia in September 2006, September 2008, and September 2009 who supported the accomplishment of the experiments. Special thanks go to Dr. A. Keller for the support in data analysis. Finally, the authors would like to thank the reviewers for their remarks.

\section{References}

[1] L. Beuselinck, G. Govers, P. B. Hairsine, G. C. Sander, and M. Breynaert, "The influence of rainfall on sediment transport by overland flow over areas of net deposition," Journal of Hydrology, vol. 257, no. 1-4, pp. 145-163, 2002.

[2] N. J. Kuhn and R. B. Bryan, "Drying, soil surface condition and interrill erosion on two Ontario soils," Catena, vol. 57, no. 2, pp. 113-133, 2004.

[3] N. J. Kuhn, R. B. Bryan, and J. Navar, "Seal formation and interrill erosion on a smectite-rich Kastanozem from NEMexico," Catena, vol. 52, no. 2, pp. 149-169, 2003.

[4] Y. Le Bissonnais, O. Cerdan, V. Lecomte, H. Benkhadra, V. Souchère, and P. Martin, "Variability of soil surface characteristics influencing runoff and interrill erosion," Catena, vol. 62, no. 2-3, pp. 111-124, 2005.

[5] I. Brodie and C. Rosewell, "Theoretical relationships between rainfall intensity and kinetic energy variants associated with stormwater particle washoff," Journal of Hydrology, vol. 340, no. 1-2, pp. 40-47, 2007.

[6] R. B. Bryan, "Soil erodibility and processes of water erosion on hillslope," Geomorphology, vol. 32, no. 3-4, pp. 385-415, 2000.

[7] G. Govers, R. Giménez, and K. Van Oost, "Rill erosion: exploring the relationship between experiments, modelling and field observations," Earth-Science Reviews, vol. 84, no. 3-4, pp. 87-102, 2007.

[8] A. Knapen, J. Poesen, G. Govers, G. Gyssels, and J. Nachtergaele, "Resistance of soils to concentrated flow erosion: a review," Earth-Science Reviews, vol. 80, no. 1-2, pp. 75-109, 2007.

[9] O. Cerdan, Y. Le Bissonnais, A. Couturier, H. Bourennane, and V. Souchère, "Rill erosion on cultivated hillslopes during two extreme rainfall events in Normandy, France," Soil and Tillage Research, vol. 67, no. 1, pp. 99-108, 2002.

[10] J. Poesen, "Transport of rock fragments by rill flow-a field study," in Rill Erosion-Process and Significance, R. B. Bryan, Ed., vol. 8 of Catena, pp. 35-54, Cremlingen, Germany, 1987.

[11] D. J. Oostwoud Wijdenes, J. Poesen, L. Vandekerckhove, and M. Ghesquiere, "Spatial distribution of gully head activity and sediment supply along an ephemeral channel in a Mediterranean environment," Catena, vol. 39, no. 3, pp. 147$167,2000$.

[12] L. Vandekerckhove, J. Poesen, D. O. Wijdenes, and T. De Figueiredo, "Topographical thresholds for ephemeral gully initiation in intensively cultivated areas of the Mediterranean," Catena, vol. 33, no. 3-4, pp. 271-292, 1998.
[13] D. E. Woodward, "Method to predict cropland ephemeral gully erosion," Catena, vol. 37, no. 3-4, pp. 393-399, 1999.

[14] G. R. Hancock, D. Crawter, S. G. Fityus, J. Chandler, and T. Wells, "The measurement and modelling of rill erosion at angle of repose slopes in mine spoil," Earth Surface Processes and Landforms, vol. 33, no. 7, pp. 1006-1020, 2008.

[15] Ries and J. B. :, "Landnutzungswandel und Landdegradation in Spanien-Eine Einführung," in Landnutzungswandel Und Landdegradation in Spanien, I. Marzolff, J. B. Ries, J. De La Riva, and M. Seeger, Eds., pp. 11-29, 2003.

[16] W. Merz, "Experimentelle Untersuchungen zur Rillenerosion auf landwirtschaftlich genutzten Böden in Kanada und der Volksrepublik China," Freiburger Geographische Hefte, Heft 40, Selbstverlag des Institutes für Physische Geographie der Albert-Ludwig-Universität Freiburg i.Br., Freiburg, Germany, 1993.

[17] J. Poesen, C. Valentin, J. Nachtergaele, and G. Verstraeten, "Gully erosion and environmental change: importance and research needs," Catena, vol. 50, no. 2-4, pp. 91-133, 2003.

[18] D. Faust and M. Schmidt, "Soil erosion processes and sediment fluxes in a Mediterranean Marl landscape, campiña de cádiz, SW Spain," Zeitschrift Für Geomorphologie, vol. 53, no. 2, pp. 247-265, 2009.

[19] L. D. Meyer, G. R. Forster, and M. J. M. Römkens, "Source of soil eroded by water from upland slopes," in Proceedings of the 1972 Sediment Yield Workshop, pp. 177-189, US Department of Agriculture, National Sedimentation Laboratory, Oxford, Miss, USA, 1975.

[20] R. P. C. Morgan, L. Martin, and C. A. Noble, "Soil erosion in the United Kingdom: a case study from Mid-Bedfordshire, England," Occasional Paper 14, 1987.

[21] R. Giménez and G. Govers, "Flow detachment by concentrated flow on smooth and irregular beds," Soil Science Society of America Journal, vol. 66, no. 5, pp. 1475-1483, 2002.

[22] R. Hessel and V. Jetten, "Suitability of transport equations in modelling soil erosion for a small Loess Plateau catchment," Engineering Geology, vol. 91, no. 1, pp. 56-71, 2007.

[23] M. Seeger, "Uncertainty of factors determining runoff and erosion processes as quantified by rainfall simulations," Catena, vol. 71, no. 1, pp. 56-67, 2007.

[24] S. Wirtz, M. Seeger, and J. B. Ries, "The rill experiment as a method to approach a quantification of rill erosion process activity," Zeitschrift Für Geomorphologie, vol. 54, no. 1, pp. 4764, 2010.

[25] S. Wirtz, M. Seeger, and J. B. Ries, "Field experiments for understanding and quantification of rill erosion processes," Catena, vol. 91, pp. 21-34, 2012.

[26] Ministerio de Fomento, Secretaria de Estado de Infraestructuras y Transportes, and Directión General de Carreteras, Máximas Illuvias Diarias En La Espana Peninsular, 1999.

[27] J. B. Ries, M. Langer, and C. Rehberg, "Experimental investigations on water and wind erosion on abandoned fields and arable land in the central Ebro basin, Aragon/Spain,” Zeitschrift Für Geomorphologie, vol. 121, pp. 91-108, 2000.

[28] T. Iserloh, W. Fister, M. Seeger, H. Willger, and J. B. Ries, "A small portable rainfall simulator for reproducible experiments on soil erosion," Soil and Tillage Research, vol. 124, pp. 131137, 2012.

[29] J. B. Ries, M. Seeger, T. Iserloh, S. Wistorf, and W. Fister, "Calibration of simulated rainfall characteristics for the study of soil erosion on agricultural land," Soil and Tillage Research, vol. 106, no. 1, pp. 109-116, 2009. 
[30] W. Fister, T. Iserloh, J. B. Ries, and R. G. Schmidt, "Comparison of rainfall characteristics of a small portable rainfall simulator and a combined portable wind and rainfall simulator," Zeitschrift Für Geomorphologie, vol. 55, no. 3, pp. 109-126, 2011.

[31] DIN 1319-1, Grundlagen Der Messtechnik-Teil 1: Grundbegriffe, Deutsches Institut für Normung e.V., 1995.

[32] J. S. Aber, I. Marzolff, and J. B. Ries, Small-Format Aerial Photography: Principles, Techniques and Geoscience Applications, Elsevier, Amsterdam, The Netherlands, 2010.

[33] J. B. Ries and I. Marzolff, "Identification of sediment sources by large-scale aerial photography taken from a monitoring blimp," Physics and Chemistry of the Earth, vol. 22, no. 3-4, pp. 295-302, 1997.

[34] J. B. Ries, "Methodologies for soil erosion and land degradation assessment in mediterranean-type ecosystems," Land Degradation \& Development, vol. 21, no. 2, pp. 171-187, 2010.

[35] A. J. Parsons, R. E. Brazier, J. Wainwright, and D. M. Powell, "Scale relationships in hillslope runoff and erosion," Earth Surface Processes and Landforms, vol. 31, no. 11, pp. 13841393, 2006.

[36] E. Amore, C. Modica, M. A. Nearing, and V. C. Santoro, "Scale effect in USLE and WEPP application for soil erosion computation from three Sicilian basins," Journal of Hydrology, vol. 293, no. 1-4, pp. 100-114, 2004.

[37] U. Scherer, Prozessbasierte Modellierung der Bodenerosion in einer Lösslandschaft [Ph.D. thesis], Fakultät für Bauingenieur-, Geo- und Umweltwissenschaften, Universität Fridericiana zu Karlsruhe (TH), Karlsruhe, Germany, 2008.

[38] W. W. Emmett, "The hydraulics of overland flow on hillslopes," US Geological Survey Professional Paper 662-A, United States Government Printing Office, Washington, DC, USA, 1970.

[39] J. Savat and J. De Ploey, "Sheetwash and rill development by surface flow," in Badland Geomorphology and Piping, Geo Books, Norwich, UK, 1982.

[40] G. Govers, "Spatial and temporal variability in rill development processes at the Huldenberg experimental site," in Rill Erosion, vol. 8 of Catena, pp. 17-34, Catena, Braunschweig, Germany, 1987.

[41] R. Evans, "Water erosion in British farmers' fields-some causes, impacts, predictions," Progress in Physical Geography, vol. 14, no. 2, pp. 199-219, 1990.

[42] W. Boon and J. Savat :, "A Nomogram for the Prediction of Rill Erosion," in Soil Conservation: Problems and Prospects, pp. 303-319, John Wiley \& Sons, Cranfield, UK, 1981.

[43] R. Giménez and G. Govers, "Interaction between bed roughness and flow hydraulics in eroding rills," Water Resources Research, vol. 37, no. 3, pp. 791-799, 2001.

[44] R. Giménez, The interaction between rill hydraulics, rill geometry, and sediment detachment: an experimental approach [Proefschrift ingedient tot het behalen van de graad van Doctor in de Wetenschappen], Katholieke Universiteit Leuven, Faculteit Wetenschappen, Department Geografie-Geologie, 2003.

[45] R. Giménez, O. Planchon, N. Silvera, and G. Govers, "Longitudinal velocity patterns and bed morphology interaction in a rill," Earth Surface Processes and Landforms, vol. 29, no. 1, pp. 105-114, 2004.

[46] D. Torri, M. Sfalanga, and G. Chisci, "Threshold conditions for incipient rilling," in Rill Erosion, vol. 8 of Catena, pp. 97-105, Catena, Braunschweig, Germany, 1987.

[47] W. Merz and R. B. Bryan, "Critical conditions for rill initiation on sandy loam Brunisols: laboratory and field experiments in southern Ontario, Canada," Geoderma, vol. 57, no. 4, pp. 357385, 1993.

[48] R. J. Loch and T. E. Donnollan, "Field rainfall simulator studies on two clay soils of the Darling Downs, Queensland. I. The effects of plot length and tillage orientation on erosion processes and runoff and erosion rates," Australian Journal of Soil Research, vol. 21, no. 1, pp. 33-46, 1983.

[49] A. J. Moss, P. Green, and J. Hutka, "Small channels: their experimental formation, nature, and significance," Earth Surface Processes \& Landforms, vol. 7, no. 5, pp. 401-415, 1982.

[50] R. J. Loch and E. C. Thomas, "Resistance to rill erosion: observations on the efficiency of rill erosion on a tilled clay soil under simulated rain and run-on water," in Rill ErosionProcesses and Significance, vol. 8 of Catena, pp. 71-83, Catena, Braunschweig, Germany, 1987.

[51] A. Cerdà, "The effect of patchy distribution of Stipa tenacissima L. on runoff and erosion," Journal of Arid Environments, vol. 36, no. 1, pp. 37-51, 1997.

[52] R. P. C. Morgan, "Soil erosion in the United Kingdom: field studies in the Silsoe area, 1973-75," Occasional Paper 4, National College of Agricultural Engineering, 1977. 

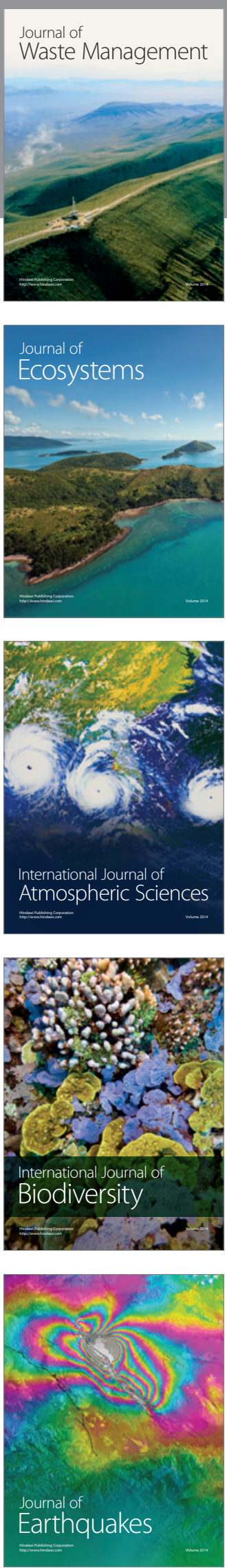
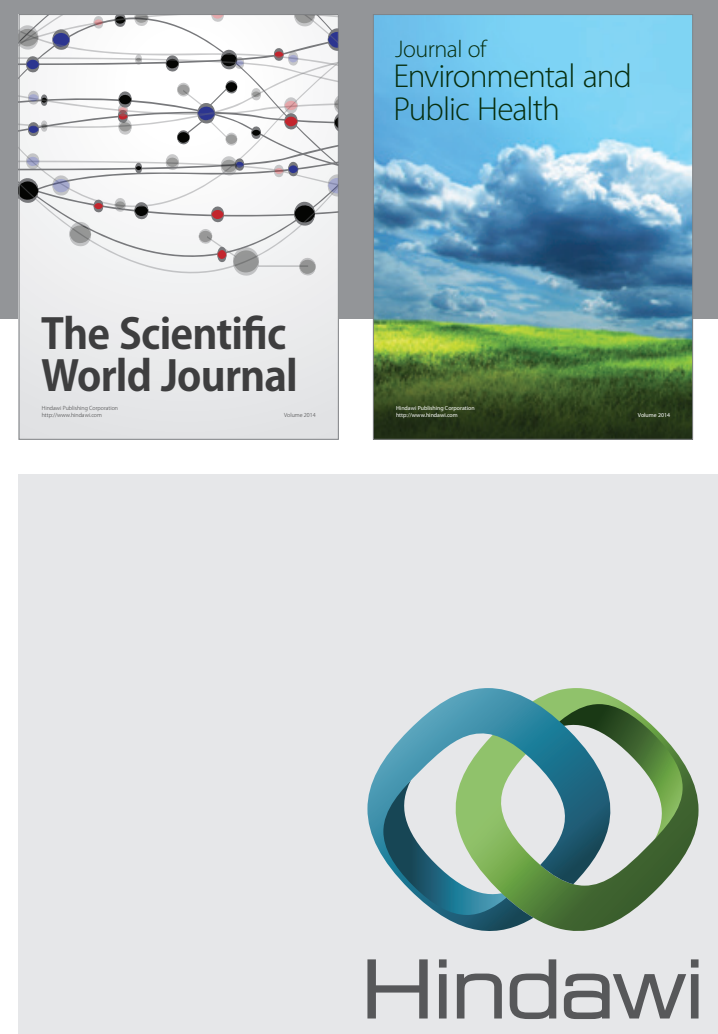

Submit your manuscripts at

http://www.hindawi.com
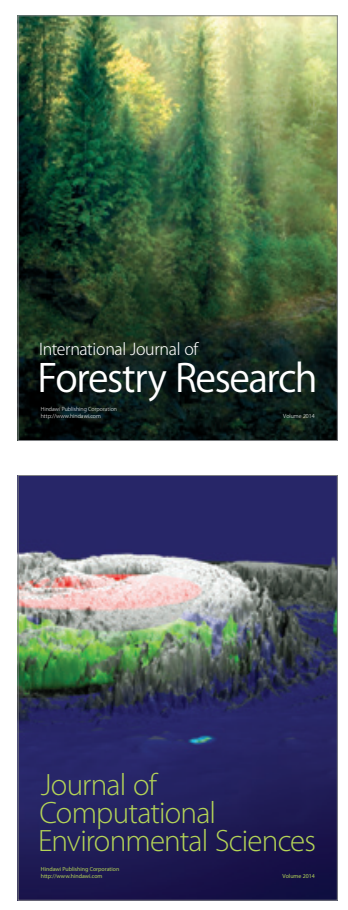
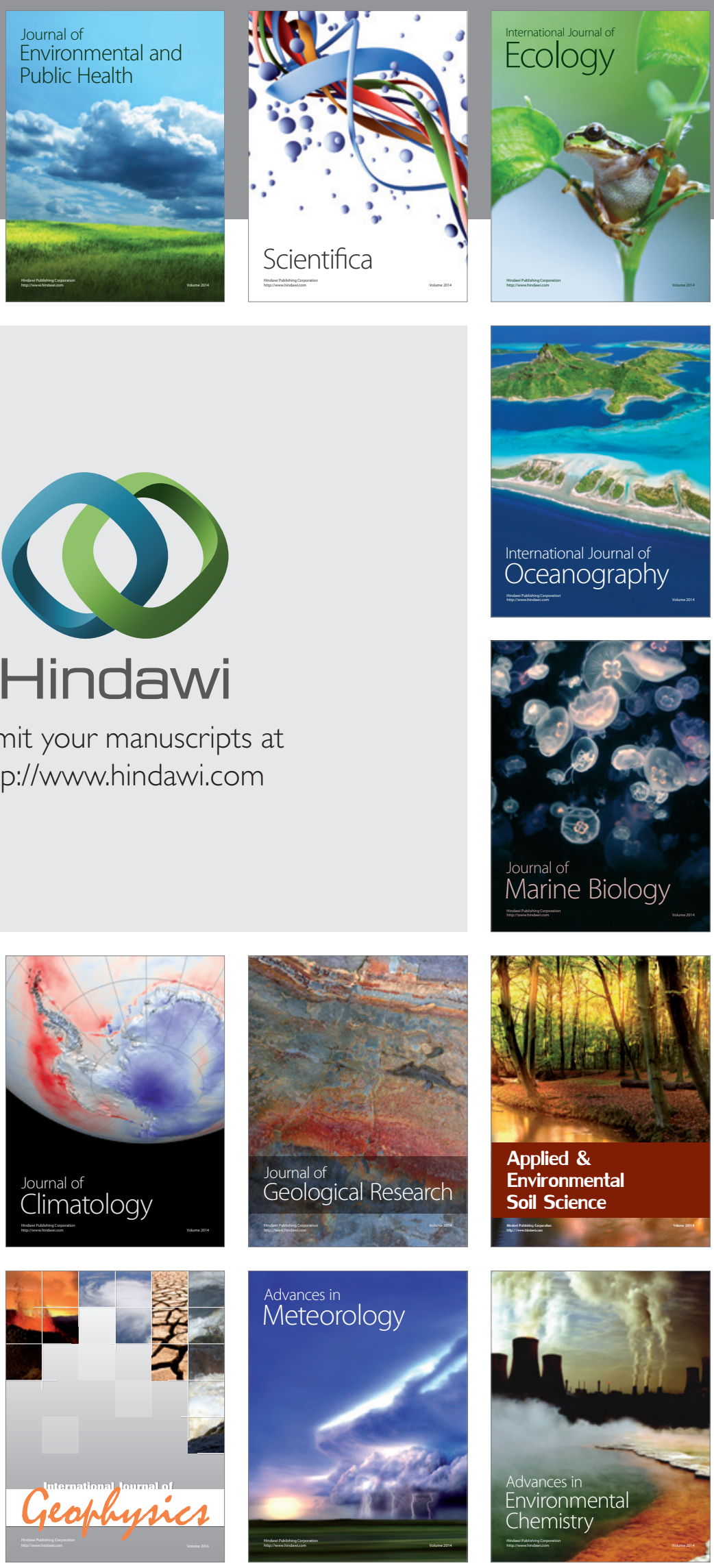